\title{
Understanding nuclear receptor form and function using structural biology
}

\section{Fraydoon Rastinejad, Pengxiang Huang, Vikas Chandra and Sepideh Khorasanizadeh}

Metabolic Signaling and Disease Program, Sanford-Burnham Medical Research Institute, Orlando, Florida 32827, USA
Correspondence should be addressed to F Rastinejad Email frastinejad@ sanfordburnham.org

\begin{abstract}
Nuclear receptors (NRs) are a major transcription factor family whose members selectively bind small-molecule lipophilic ligands and transduce those signals into specific changes in gene programs. For over two decades, structural biology efforts were focused exclusively on the individual ligand-binding domains (LBDs) or DNA-binding domains of NRs. These analyses revealed the basis for both ligand and DNA binding and also revealed receptor conformations representing both the activated and repressed states. Additionally, crystallographic studies explained how NR LBD surfaces recognize discrete portions of transcriptional coregulators. The many structural snapshots of LBDs have also guided the development of synthetic ligands with therapeutic potential. Yet, the exclusive structural focus on isolated NR domains has made it difficult to conceptualize how all the NR polypeptide segments are coordinated physically and functionally in the context of receptor quaternary architectures. Newly emerged crystal structures of the peroxisome proliferatoractivated receptor- $\gamma$-retinoid $X$ receptor $\alpha(P P A R \gamma-R X R \alpha)$ heterodimer and hepatocyte nuclear factor (HNF)-4 $\alpha$ homodimer have recently revealed the higher order organizations of these receptor complexes on DNA, as well as the complexity and uniqueness of their domain-domain interfaces. These emerging structural advances promise to better explain how signals in one domain can be allosterically transmitted to distal receptor domains, also providing much better frameworks for guiding future drug discovery efforts.
\end{abstract}

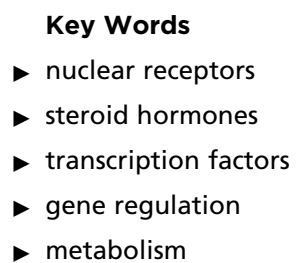

Journal of Molecular Endocrinology (2013) 51, T1-T21

\section{Introduction}

As transcription factors, nuclear receptors (NRs) bind directly to lipophilic ligands, such as steroids, thyroid hormone, retinoids, and dietary lipids, and respond by regulating gene expression programs (Mangelsdorf \& Evans 1995, Mangelsdorf et al. 1995, Gronemeyer et al. 2004). NRs have long been exploited as therapeutic drug targets. Molecules such as tamoxifen for estrogen receptors (ERs) used for breast cancer, thiazolidinediones for peroxisome proliferator-activated receptor- $\gamma(\operatorname{PPAR} \gamma)$ used for type 2 diabetes, mifepristone for the progesterone receptor (PR) used for fertility, and dexamethasone for the glucocorticoid receptor (GR) used for inflammatory diseases are among the prominent examples of prescription drugs that target NRs (Gronemeyer et al. 2004). By some estimates, NR ligands constitute 10-20\% of the worldwide pharmaceutical market (Ottow \& Weinmann 2008).

With their remarkable property of transducing chemical signals from their ligands into changes in gene 
expression, structural biologists recognized early on the importance of obtaining mechanistic insights into how these polypeptides are folded and able to recognize their DNA and ligand molecules. For more than two decades now, structural efforts on discrete segments of NR have provided critical information regarding how ligands bind to the receptors with selectivity, which receptor conformations are consistent with the transcriptionally active or inactive states, how DNA recognition and receptor dimerization are achieved, and how different types of coregulators are recruited. Yet, our understanding of how the entire receptor polypeptides act in a concerted fashion using all its domains, dimerization states, ligands, and DNA has only recently been unveiled through crystallographic advances. Here, we review the most important lessons learned from the crystallographic studies on individual domains and also describe the newer findings based on nearly complete NR polypeptides arranged in their functionally revealing complexes.

Figures $1 \mathrm{~A}, \mathrm{~B}$ and $\mathrm{C}$ show the domain arrangement of NRs within their polypeptides. NRs form a wide variety of dimeric states and bind to a variety of DNA response elements consisting of direct repeat (DR) elements, palindromic (inverted) repeats, or extended monomeric sites (Fig. 1D). From these response elements, NRs then further recruit other complexes that bring repression or activation to their target genes (Fig. 1C). The coregulator complexes that are recruited have the ability to modify histone tails and alter chromatin structure to promote or repress transcription. In the absence of ligands, some NRs recruit the binding of corepressor, such as nuclear receptor corepressor 1 (N-CoR1) or silencing mediator for retinoid and thyroid hormone receptor (SMRT), which further recruit histone deacetylases. In the activated state, NRs recruit coactivators that link the status of the ligand-activated NRs to the chromatin state, by recruiting of complexes that differentially modify histone tails. The coactivator-containing complexes typically harbor histone acetyltransferase activity (McKenna et al. 1999, Glass \& Rosenfeld 2000). The DNA binding domain (DBDs) and ligand binding domains (LBDs) of most NRs are now relatively well understood structurally, and our
A
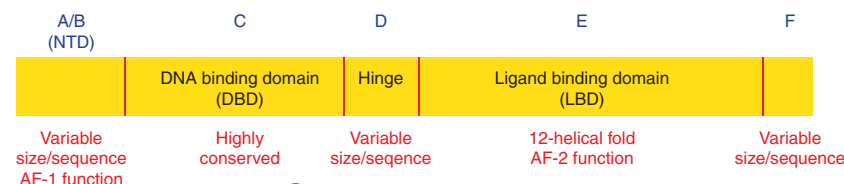
AF-1 function conserved AF-2 function

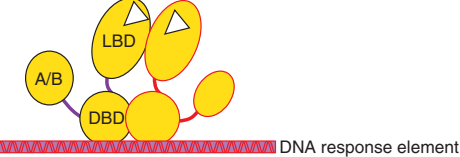

C

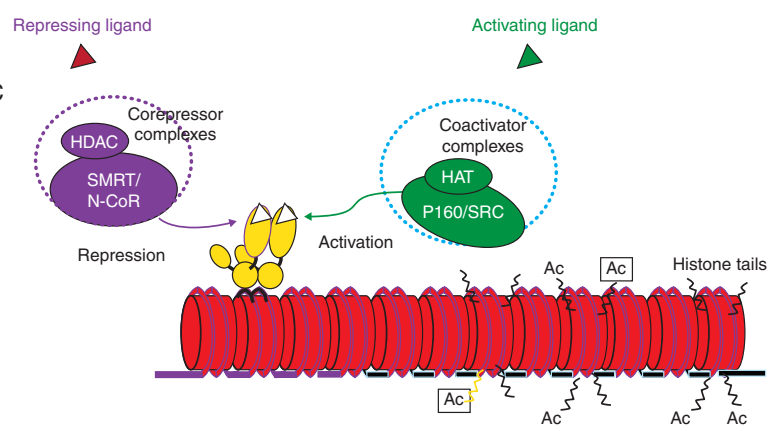

Figure 1

Domain organization of NRs and their interaction partners. (A) NR polypeptides have an N-terminal domain (NTD) that is variable in size and sequence, a conserved DBD, a variable hinge region, and a 12-helical LBD. Several NRs also contain a variable F-domain positioned at their C-termini. (B) Schematic showing how a dimeric NR uses different domains to bind to DNA and ligand. (C) NRs can be modulated by ligands that either activate or repress gene targets. Repression is mediated by complexes that have corepressors (SMRT/N-CoR and histone deacetylases (HDACs)), among other components. Activation requires the coactivator complexes ( $\mathrm{p} 160$ family members and histone acetyltransferase (HAT)). The repressive and activating

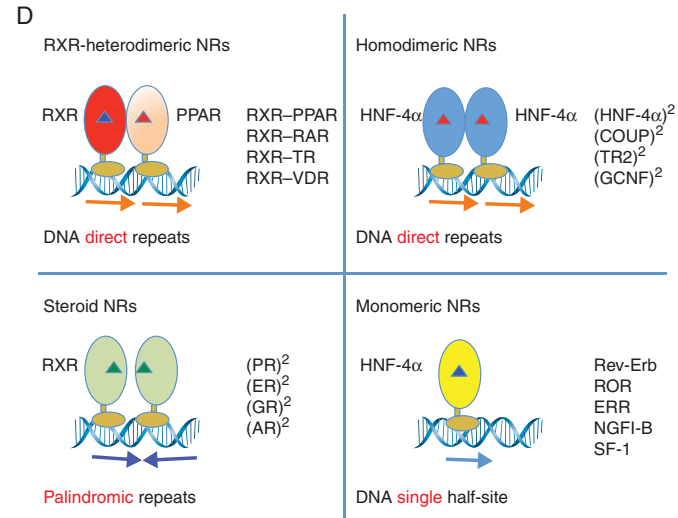

complexes block or promote transcription. (D) Oligomeric complexes of NRs and DNA response element repertoires. Receptors can be organized into distinct oligomeric states such as heterodimers with the common partner retinoid $X$ receptor ( $R X R)$, homodimers, or monomers. The non-steroid receptor heterodimers and many homodimers bind to direct repeat response elements with various inter-half-site spacings. Steroid receptor homodimers mainly use palindromic DNA elements, where the two half sites are in an inverted repeat arrangement. Other receptors use monomeric sites extended at their $5^{\prime}$-end with short sequences used for selectivity. Several examples of receptors falling into each of these four categories are shown.

Published by Bioscientifica Ltd 


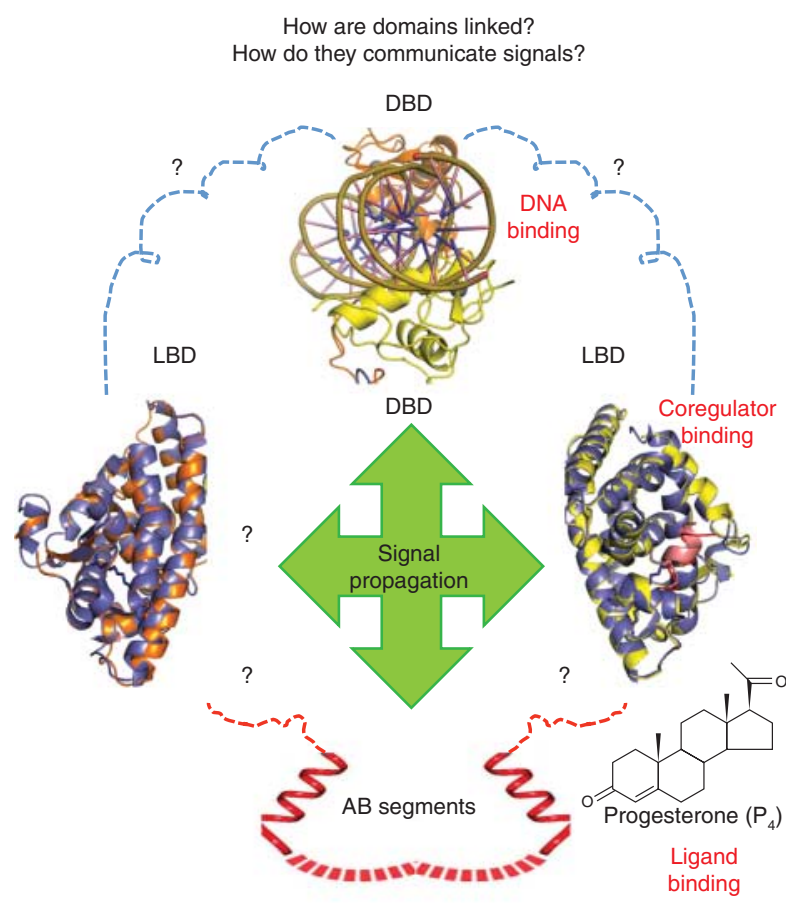

Figure 2

Understanding domain-domain integration in nuclear receptors requires structural studies that utilize the complete receptor complexes. A major goal has been to understand allosteric communication: how signals in one domain may be efficiently transmitted to a distal domain in the quaternary fold (Chandra et al. 2008, 2013).
A

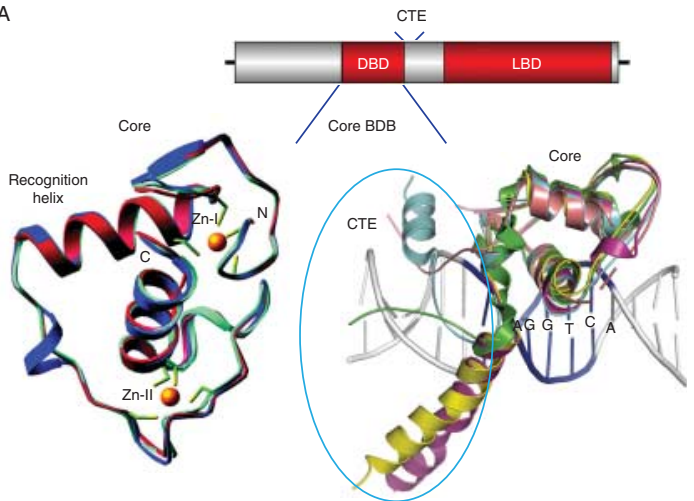

understanding of their architecture and functional properties is summarized in this review. We also describe the more recent structural studies on multi-domain NR complexes and what they have recently revealed about the higher order quaternary organization of NRs and the possibility of allosteric communications in their complexes (Fig. 2).

\section{The DBD and response element recognition}

Early studies based on domain swapping and the characterization of DBD-DNA interactions suggested that this domain mediates the receptor's entire ability to bind response elements in an independent and selfcontained manner (Green \& Chambon 1987, Kumar et al. 1987, Umesono \& Evans 1989). The centrally positioned DBDs were also recognized to be the most conserved segments of NR polypeptides, and accordingly, they closely share the same overall three-dimensional structure, as shown in Fig. 3A (Khorasanizadeh \& Rastinejad 2001). Eight perfectly conserved cysteine residues coordinate two zinc ions to maintain the overall core DBD fold, which encompasses a total of 66 amino acid residues. Two $\alpha$-helices that pack in a perpendicular fashion are contained in this core unit, one of which is responsible for DNA half-site recognition. The binding of the zinc ions to the DBD was initially confirmed through
B

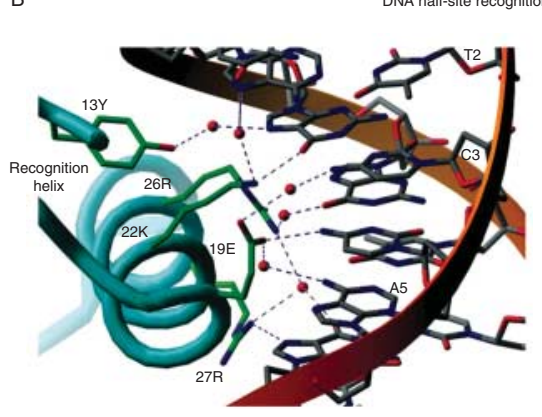

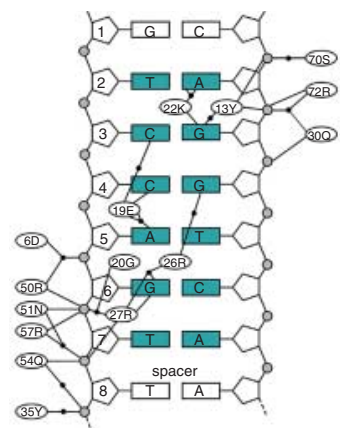

\section{Figure 3}

The basis for DNA recognition. (A) The core DBD is the 66-residue region with two zinc-binding modules. This domain is responsible for the recognition of hexameric DNA half sites. Shown on the left are the core DBD structures of RXR (blue) and RAR (red) superimposed. The C-terminal extension (CTE) of the DBD, which lies within the immediate hinge region, can also participate in DNA binding and spacer recognition. Shown on the right is the superposition of the DBD-CTE segments of NGFI-B (green), LRH-1 (cyan), VDR (yellow), TR (magenta), and Rev-Erb (salmon). While the core DBDs are well conserved in folding, the CTE sequences and their structures are divergent. The CTEs can act as discriminators of DNA spacing. (B) RAR DBD interactions with AGGTCA elements. DNA half-site recognition by NRs involves a series of hydrophilic residues positioned on the same face of the DBD recognition helix. These residues read the DNA base pair sequence at the major groove. Other basic amino acids additionally stabilize DNA binding by interacting with the phosphate backbone of the DNA. Crystallographic studies have shown that water molecules (shown as red or black circles) often help mediate DNA contacts. http://jme.endocrinology-journals.org DOI: 10.1530/JME-13-0173
(C) 2013 Society for Endocrinology Printed in Great Britain
Published by Bioscientifica Ltd 
an Extended X-ray Absorption Fine Structure (EXAFS) study (Freedman et al. 1988).

The first structural characterizations of the isolated DBDs used nuclear magnetic resonance (NMR)-based approaches focusing on the ER, GR, and retinoic acid receptor $\beta$ (RAR $\beta)$ (Hard et al. 1990, Schwabe et al. 1990, Knegtel et al. 1993). These studies identified the secondary structural elements of the DBDs and confirmed that the overall folding was highly similar in all three receptors. These key lessons derived from NMR studies were soon expanded by more comprehensive studies that used X-ray crystallography with ER and GR, in each case as a homodimeric DBD complex bound to DNA (Luisi et al. 1991, Schwabe et al. 1993). A key finding was that one helix inserts directly into the major groove of the conserved hexamers present in the DNA response elements. GR, PR, the androgen receptor (AR), and the mineralocorticoid receptor use the same consensus 5'-AGGACA-3' conserved half sites, whereas ER and most non-steroid receptors use $5^{\prime}$-AGGTCA-3' half sites. Accordingly, these two receptor groups also use distinct sets of amino acids on the exposed face of their DNA recognition $\alpha$-helices. As shown in Fig. 3B, water molecules are very much involved in the DNA major groove interactions and can also support the interactions of the DBD residues with the phosphate backbone of their response elements.

While the recognition $\alpha$-helix accounts for half-site binding, this type of interaction alone did not fully account for response element selectivity in the NR family, because there are only two major types of consensus DNA hexamers and there is a high degree of sequence conservation in the DBD amino acid sequences within the family. Later, it became clear that DNA target selectivity relies in great part on the geometry associated with a response element when two half sites are arranged in various bipartite fashions (Figs 1D and 4; Umesono et al. 1991, Mader et al. 1993, Perlmann et al. 1993). To recognize the geometry using their binding sites, dimeric receptors are required to cooperate on bipartite response elements as correctly paired homodimers or heterodimers. The DNA half sites can be arranged as DRs or palindromic (inverted) repeats. Half-site spacing is crucial for establishing response element selectivity, as each additional spacer between the repeats displaces the half sites by $3.4 \AA$, and $\sim 35$ degrees, so that only the correct receptor pairs can interact productively.

Structural studies on multiple DBD-DNA complexes proved successful, as shown in Fig. 4 (Rastinejad et al. 1995, 2000, Zhao et al. 1998, 2000, Meinke \& Sigler 1999, Sierk et al. 2001, Shaffer \& Gewirth 2002, Devarakonda et al. 2003, Shaffer et al. 2004, Solomon et al. 2005, Little et al. 2006, Roemer et al. 2006, Lu et al. 2008). The dimeric complexes show that DBDs associate with significant cooperativity on the correctly configured DNA sites. The basis for the binding cooperativity lies in the proteinprotein contacts that the DBDs form within the spacer minor groove. The DBDs form these DNA-dependent dimer interfaces in a manner that does not interfere with the proper registration of each recognition helix inside the DNA major grooves within the half sites (Luisi et al. 1991).

When the DNA is absent, DBD-DBD interactions cannot occur, as the spacer minor groove is an active component in this dimerization process. Indeed, the minor groove provides a very sheltered environment for polar residues to interact between the two DBDs, without interference from bulk solvent. NMR studies carried out on the GR DBD complex with DNA have suggested an allosteric communication pathway that signals between the DNA and the dimerization interfaces of the DBDs (Watson et al. 2013). While structural studies involving DBD/DNA complexes have now shown why the 3-bp spacing in a GR or PR response element is necessary for cooperative DBD interactions and DNA recognition, it remains to be explained how the selectivity in binding-site repertoires is generated for steroid receptor homodimers, as most of them use the same symmetry, spacing, and consensus half-site sequences (Luisi et al. 1991, Roemer et al. 2006). It is likely that other unique sites flanking the $3^{\prime}$ or $5^{\prime}$ half sites of these symmetric repeats allow for selectivity, a notion that was supported by the crystal structure of PR DBD on DNA (Nelson et al. 1999, Roemer et al. 2006). Moreover, other bipartite configurations of the consensus half-site motifs, or possibly other collaborating transcription factors, are likely to provide additional specifying queues for establishing response element selectivity physiologically.

The retinoid X receptor (RXR) has been proven to be a special member of the NR family, as it can form heterodimers with a variety of non-steroid receptors (Yu et al. 1991, Bugge et al. 1992, Hallenbeck et al. 1992, Kliewer et al. 1992a,b, Leid et al. 1992, Marks et al. 1992, Zechel et al. 1994a,b, Forman et al. 1995). The dimerization partners of RXR include the RAR, vitamin $\mathrm{D}_{3}$ receptor (VDR), thyroid hormone receptor (TR), PPAR, and several other receptors (Fig. 1D). As with the steroid receptors, the DBDs of RXR and its heterodimeric partners are unable to efficiently interact in the absence of DNA. But in the presence of the correct response elements, they produce the same patterns of DNA selectivity as their fulllength receptors. The RXR heterodimers use high-affinity

Published by Bioscientifica Ltd 

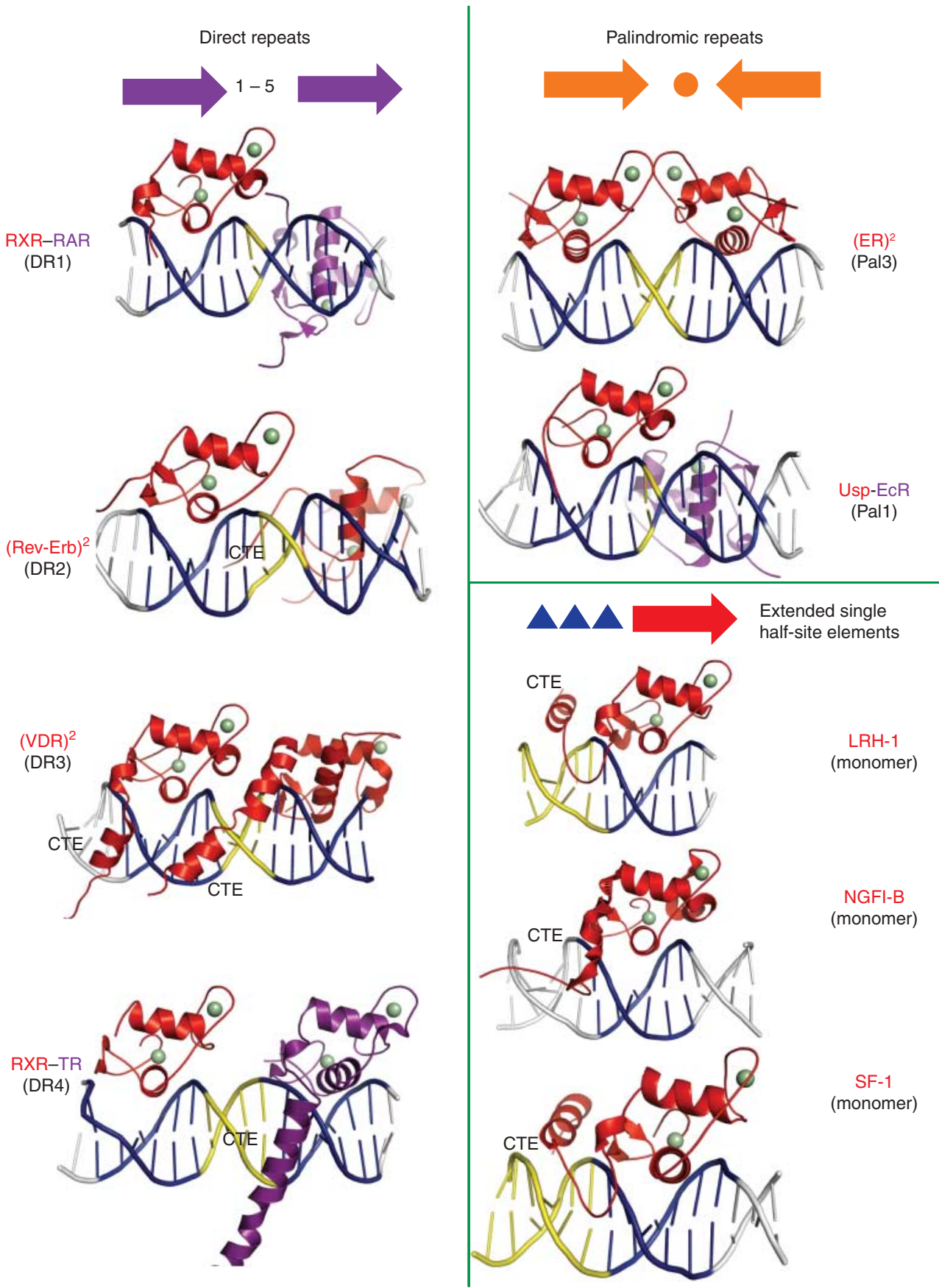

\section{Figure 4}

The interactions of DBDs with response elements. Shown are structures of NR DBD homodimers, heterodimers, and monomers on response elements consisting of direct repeats (DRs), palindromes (Pal), and single half sites. The spacer size has a dramatic effect on the relative rotation and displacement of the two DBDs, fostering their productive dimerization

response elements consisting of DRs with distinct half-site spacings (Umesono et al. 1991, Mader et al. 1993, Perlmann et al. 1993). These spacings range between 1 and $5 \mathrm{bp}$ (with their corresponding DR elements referred

contacts on the correctly spaced element, but blocking their dimerization when the spacing size is incorrect. Monomeric NRs use the same consensus half sites but rely on the immediate flanking base pairs upstream of their half site for response element discrimination.

to as DR1-DR5). The pattern of site selectivity based on the spacing of DRs is known as the 1-5 rule (Umesono et al. 1991). Whereas RXR can form DBD-DBD interactions productively with a partner such as TR on DR4, a change in

Published by Bioscientifica Ltd 
the spacing size would block these interactions, causing RXR to require a different heterodimerization partner instead. Curiously, the RXR homolog in Drosophila, known as ultraspiracle (Usp), uses a palindromic DNA site, instead of DRs, to form a heterodimer with the ecdysone receptor, as shown in Fig. 4.

In contrast to palindromic binding sites used by steroid receptor homodimers, the individual half sites in a DR element can further be distinguished according to their upstream or downstream location. In RXR heterodimers, RXR can be positioned alternately at the upstream or downstream half-site relative to its partner. RXR-RAR complexes on DR1 and DR5 form with opposite polarity and these, in turn, have different responses to ligands and corepressors (Kurokawa et al. 1994). Structural studies confirmed that RXR could bind to opposing half sites depending on the choice of its heterodimerization partners. Figure 4 shows the RXR-RAR DBD complex in which RXR is positioned downstream of its partner, and the RXR-TR DBD heterodimer, where RXR is positioned upstream of its partner (Rastinejad et al. 1995, 2000). In the full-length RXR-PPAR heterodimer on DR1, RXR was found to be located on the downstream half site (Chandra et al. 2008). As with the steroid receptors, structural studies on RXR DBD heterodimers have also taught us that the DBDs form their protein-protein interactions inside the minor groove of the spacer (Rastinejad et al. 1995, 2000, Zhao et al. 2000). An important lesson from these studies is that the interactions between the DBDs of RXR and its partners are not hardwired. Instead, they are adaptable to their DNA binding sites and can undergo induced fit at locations required for dimerization and minor groove binding.

Within the context of the full-length receptors, it was also suggested that the relative location of the two receptors could have profound consequences, in terms of constraining the patterns of domain-domain interactions and the response to ligands. The potential consequences on the quaternary organization were recognized to include the possibility of restricting one partner from interacting with ligands or coregulators (Kurokawa et al. 1994). Since RXR heterodimerizes with many NRs, another intriguing issue has been whether each member of a heterodimer needs its own ligand for the heterodimer to be active (Germain et al. 2002). Indeed, RXR can act as a silent or an active partner in these heterodimers. In RAR/RXR, TR/RXR, and VDR/RXR heterodimers, there is little or no transcriptional activity without the RXR ligand, and these are referred to as 'non-permissive' complexes, as ligands for both heterodimeric partners are required. In 'permissive' complexes, such as
PPAR/RXR, liver X receptor (LXR)-RXR, and Farnesoid X receptor (FXR)-RXR, ligands for either partner are sufficient for robust transcriptional activation (Germain et al. 2002). The permissive status of the PPAR $\gamma$-RXR heterodimers has allowed for RXR binding agonists to be developed that would show similar actions physiologically to PPAR $\gamma$ ligands, such as in sensitizing diabetic mice to insulin (Mukherjee et al. 1997).

While many NRs rely on dimeric arrangements, some receptors bind to DNA as monomers and function without partners (Fig. 4). Monomeric receptors include nerve growth factor-induced B (NGFI-B, also known as NURR77), Rev-Erb, ROR, and steroidogenic factor-1 (SF-1) (Figs 1D and 4; Wilson et al. 1993, Giguere et al. 1995, Harding \& Lazar 1995, Charles et al. 1999). The Rev-Erb DBD/DNA crystal structure first showed how a DBD could rely on a portion of the NR hinge region, named the C-terminal extension (CTE) of the DBD, to extend its DNA binding footprint for efficient monomeric binding (Zhao et al. 1998). The site of the DNA contacted by the CTE is positioned directly upstream of the single consensus half site. An examination of Rev-Erb CTE sequences alongside other NR CTE sequences suggested how certain other NRs would similarly recognize extended half sites (see Fig. 3A; Zhao et al. 1998). Later studies on NGFI-B and liver receptor homolog-1 (LRH-1) and SF-1 DBDs verified the predicted mode of minor groove interactions by their CTE, which always involved the $5^{\prime}$ extension of the half site (Meinke \& Sigler 1999, Solomon et al. 2005, Little et al. 2006). In receptors that form dimeric arrangements on DNA, the CTE regions can also have the important role of acting as a 'ruler' by measuring the size of the inter-halfsite spacer to ensure that a heterodimer is using its correctly spaced response element (Rastinejad et al. 1995, Zhao et al. 1998).

\section{The LBDs and the concept of receptor activation}

The NR LBDs have a similar overall conformation consisting of a three-layered helical sandwich. The LBD is characterized by a hydrophobic cavity or pocket in which lipophilic ligands are captured and shielded from the solvent environment. While the overall architectures of NR LBDs may look strikingly similar, the ligand pockets within these LBDs are sufficiently unique in size and character, with diverse amino acid compositions that ensure specificity for endogenous ligands. Given that the endocrine steroid receptors, VDR, LXR, and FXR, recognize ligands that have a similar overall cholesterol-derived

Published by Bioscientifica Ltd 
chemical frame, it is remarkable that these pockets so clearly exclude all but the correct ligands for each receptor. When a group of 48 human NRs were examined, the LBD pockets have a volume from 0 (i.e. totally absent due to the pocket being filled with hydrophobic side chains from the LBD) to more than $1500 \AA^{3}$ (Li et al. 2003). Non-polar residues predominantly line these pockets, with one or more polar residues also present in the pocket that allow effective hydrogen bonding with hydrophilic groups that may be present on some NR ligands. These pockets discriminate their ligands using van der Waals forces to detect the surface and shape features of lipophilic ligands.

The three-dimensional crystal structures of most of the 48 NR LBDs have been deposited in the Protein Data Bank (PDB). Notable exceptions are the homolog of the Drosophila tailless gene (TLX), the neuron-derived orphan receptor 1 (NOR-1), the photoreceptor cell-specific NR (PNR), and the germ cell nuclear factor (GCNF). Most of crystallized LBDs could only be studied in the liganded state (Gronemeyer et al. 2004, Nagy \& Schwabe 2004, Huang et al. 2010). There are fewer unliganded LBD crystal structures because the absence of the ligand typically destabilizes the LBD polypeptide, making it challenging to crystallize. RXR $\alpha, \operatorname{PPAR} \gamma$, NURR1, the estrogen-related receptor $\gamma(\mathrm{ERR} \gamma)$, the pregnane $\mathrm{X}$ receptor, LRH-1, TR4, and COUP-TFII are among the human unliganded LBDs that have been structurally characterized (Bourguet et al. 1995, Nolte et al. 1998, Greschik et al. 2002, Sablin et al. 2003, Wang et al. 2003, Watkins et al. 2003,
Kruse et al. 2008, Zhou et al. 2011). Figures 5, 6, 7 and 8 show some of the general features of LBDs. A key observation was the conformational switch that is shown in Fig. 5A. This switch was described in the context of the RAR LBDs, by comparing the apo-state to the liganded state. The actual basis for developing this concept came from separate X-ray crystallographic studies on different receptor, one being the apo-RXR LBD and the second being ligand RAR LBD (Bourguet et al. 1995, Renaud et al. 1995, Wurtz et al. 1996). In this model, activating ligands reposition helix-12 (H12), as well as causing smaller rearrangements elsewhere (Nagy \& Schwabe 2004). In the unligand state, H12 is far away from the body of the $\mathrm{LBD}$, and in the liganded and active state, it moves proximal to the ligand, helping to trap it in the pocket as in a mousetrap (Wurtz et al. 1996).

Despite the elegance of the mousetrap model for receptor activation, further examination of NR unligand structures could not show any other NR that used the same mousetrap mechanism. More typically, it was observed that $\mathrm{H} 12$ appeared to be in the active conformation closing atop the ligand, even in the absence of ligand in the cavity (Nagy \& Schwabe 2004). Therefore, an alternative 'dynamic stabilization' model was evoked to describe the differences between the active and inactive states of LBDs. In the apo-state, H12 is not fixed in any single position, but rather mobile along with other portions of the LBD, resembling a molten state. Ligands stabilize the receptor folding globally, lowering the degree

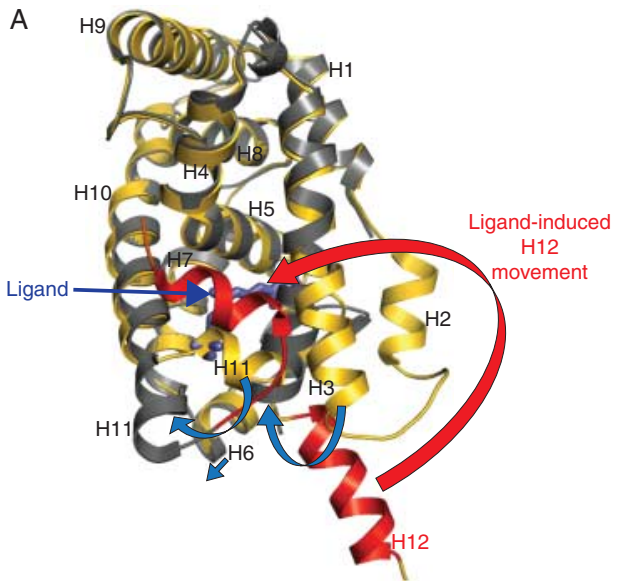

B

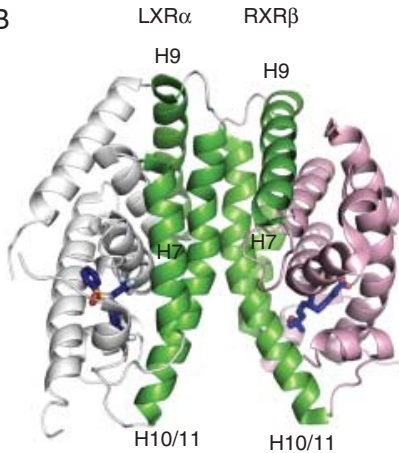

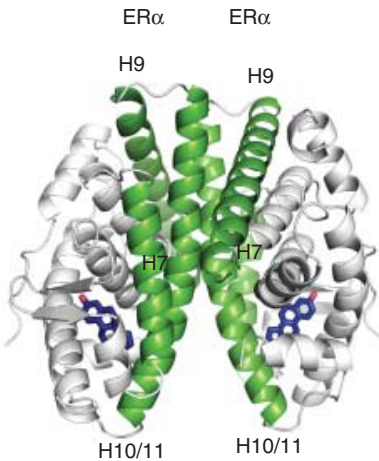

\section{Figure 5}

Structural properties of NR LBDs. (A) The comparison of the unligand RXR $\alpha$ with the liganded RAR $\gamma$ first suggested that ligands can induce multiple changes in the LBD conformation, most strikingly in the positioning of helix-12 (H12). The movement of $\mathrm{H} 12$ (shown in red) allows the ligandbinding pocket to become enclosed to prevent ligand escape, in what can be described as a trapping mechanism. Other smaller rearrangements are additionally induced by ligand binding (blue arrows). (B) Typical dimerization surfaces that form between receptor LBDs. Shown here are the LXR-RXR LBD heterodimer and the ER LBD homodimer. For two LBDs to dimerize, surfaces from $\mathrm{H} 7, \mathrm{H} 9$, and $\mathrm{H10} / 11$ participate in forming the dimeric interfaces. http://jme.endocrinology-journals.org DOI: 10.1530/JME-13-0173
๑) 2013 Society for Endocrinology Printed in Great Britain
Published by Bioscientifica Ltd 


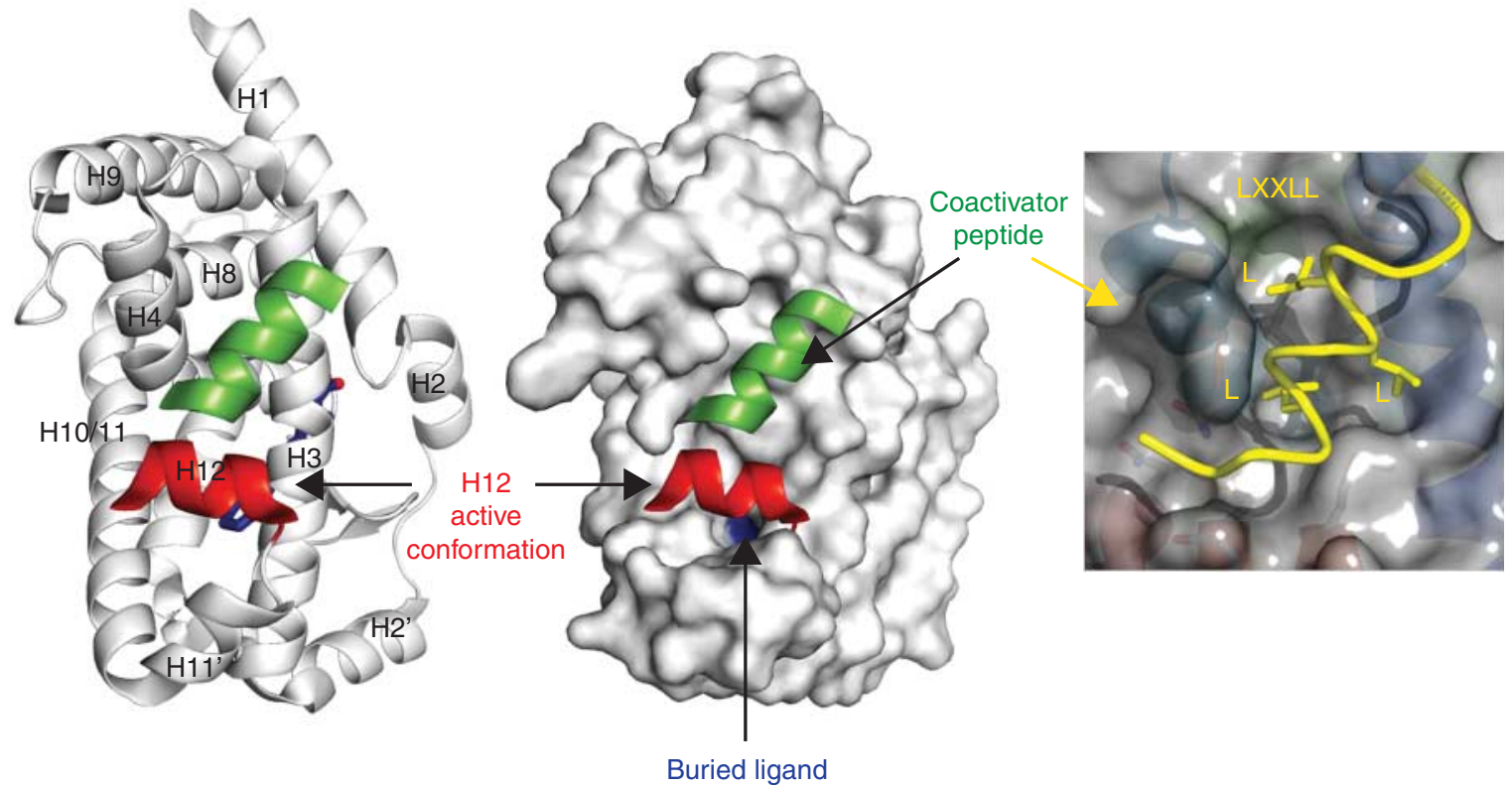

\section{Figure 6}

Coactivator binding to the surface of the LBD. (A) Shown is the ROR $\beta$ LBD structure with an agonist ligand (blue) that places helix-12 (H12) in the active conformation. From this position, $\mathrm{H} 12$ fosters the interactions of an LXXLL motif contained in most p160 coactivators with the surface of the LBD. The LXXLL motif forms a small helical segment, allowing the leucines

of conformational dynamics overall including fixing $\mathrm{H} 12$ in stable position and stabilizing the surface elements required for coactivator binding. If a receptor without ligand is already conformationally stable, then it is likely to show constitutive transcriptional activity. This notion appears to be supported for a subset of NRs exemplified by NURR1, which are constitutively active, and also have a highly stable conformation in the apo-state (Wang et al. 2003).

In other NRs that require ligand binding for activation, ligand filling of the interior often stabilizes the global conformation and reduces the dynamic motions on the LBD surface. The LBD surface is precisely where coactivators bind, and a groove is needed on the surface to capture the interacting portion of coactivators (Fig. 6). The dynamic stabilization model of receptor activation has been well supported by a variety of biophysical and biochemical methods. For example, fluorescence studies showed that $\mathrm{H} 12$ is more dynamic in the apo-PPAR $\gamma$ LBD compared with the liganded state of this protein (Kallenberger et al. 2003). In the standard view of receptor LBD structures, as shown in Figs 5, 6, 7 and 8, the lower portion of the LBD is more 'molten' than the top portion of the LBD, when ligands are absent. Support for this concept comes from NMR studies, as well as the along one face to firmly dig into a hydrophobic groove on the surface of the LBD. The $X$ residues in the coactivator motif are typically polar and interact with the solvent. Notice that the ligand (blue) is shielded from solvent when $\mathrm{H} 12$ is in the active conformation.

crystallographic temperature $(B)$ factors of these regions in LBD structures (Nolte et al. 1998, Johnson et al. 2000). Proteolytic sensitivity studies, as well as secondary structure melting studies, on LBDs further support the concept that ligand activation switches a relatively unstable LBD fold to a more rigid and wellordered conformation (Leng et al. 1993, Keidel et al. 1994, Pissios et al. 2000, Nagy \& Schwabe 2004, Raghuram et al. 2007).

Given the potential importance of LBD dynamics to receptor activation, it is important to point out that crystallographic methods are not well suited for obtaining dynamic information about protein structures, instead capturing 'snapshots' of structurally stable states of macromolecules. NMR and hydrogen-deuterium exchange mass spectrometry (H/D EMS) applied to some NRs proved much better at characterizing the dynamic states of these proteins (Johnson et al. 2000, Bruning et al. 2007, Dai et al. 2009, Zhang et al. 2010, Hughes et al. 2012). H/D EMS has proven to be a particularly powerful tool in this regard because it can be successfully applied to large NR complexes consisting of all the domains, dimerization partners and DNA, as exemplified in the case of RXR-PPAR and RXR-VDR full-length complexes. (Chandra et al. 2008, Zhang et al. 2011). Thus far, NMR studies have

Published by Bioscientifica Ltd 
<smiles>CCC(C)(c1ccc(O)cc1)c1ccc(O)cc1</smiles>

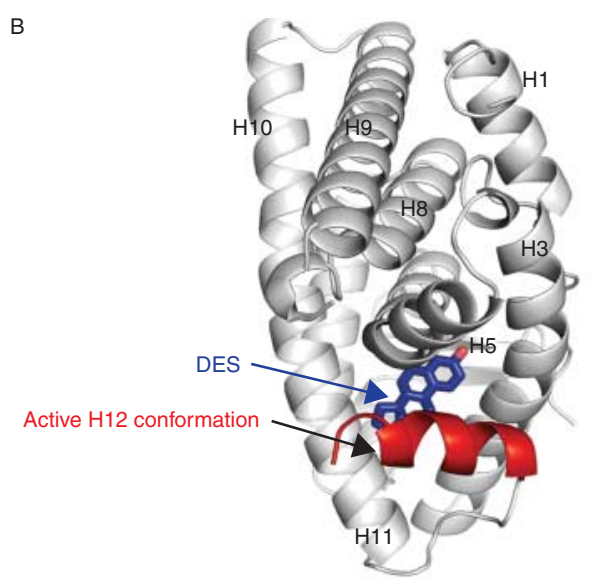

c

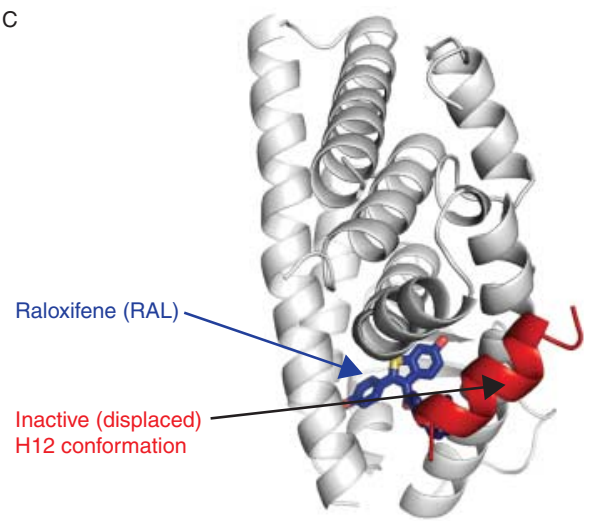

Figure 7

Structural understanding of how agonists and antagonists mediate their effects on the estrogen receptor. (A) Both estradiol and the synthetic molecule diethylstilbestrol (DES) are agonists, whereas tamoxifen and raloxifene are antagonists. The antagonists differ from stilbesterol only in

been limited to truncated complexes of NRs. As the molecular weight of the polypeptide increases, the signal overlap and slower tumbling dynamics of the complex prohibit analysis by NMR.

Whether one subscribes to the mousetrap mechanism or the dynamic stabilization model, the importance of the H12 structure for receptor activation remains central, because in the active form of receptors, attained
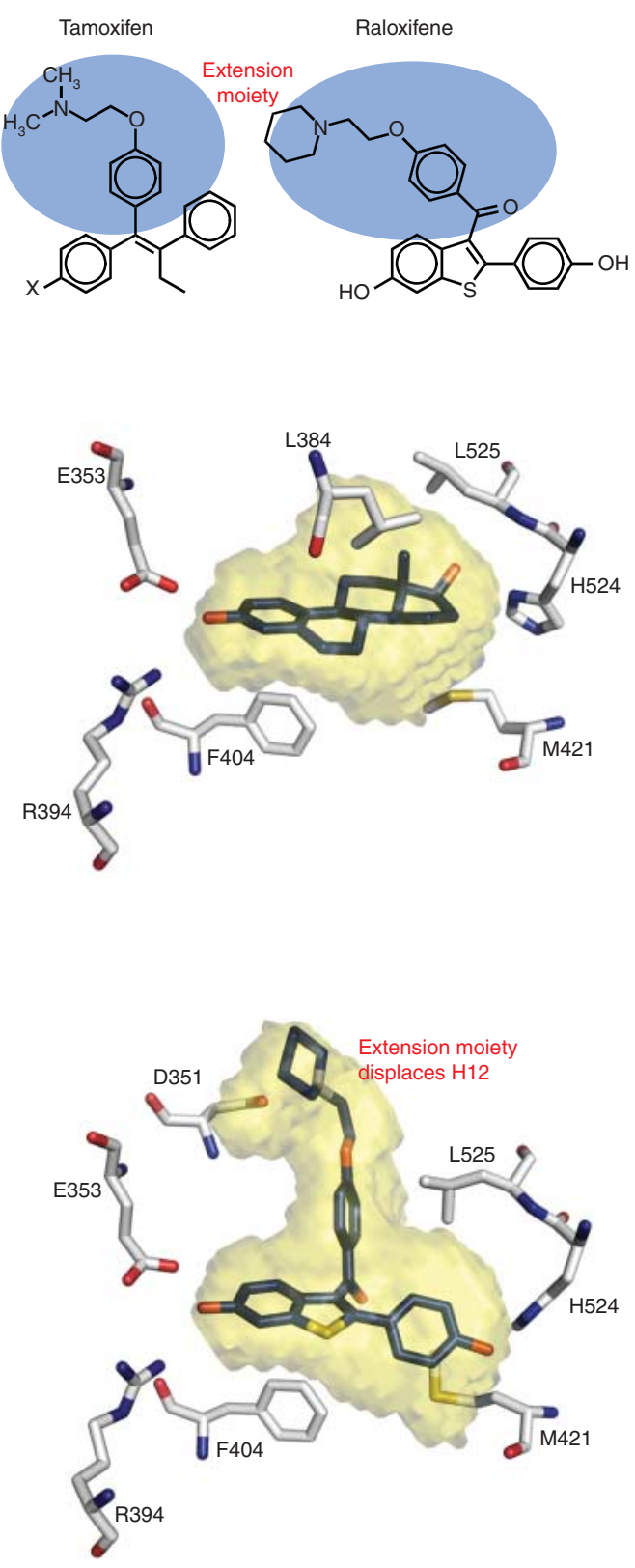

the addition of the extension moiety (in blue). (B) DES binding places helix-12 (H12) in the agonist conformation, as does estradiol.

(C) The extension moiety in raloxifene pushes $\mathrm{H} 12$ out of its active conformation.

constitutively or through ligand binding, H12 participates directly in recruiting and stabilizing coactivators onto the surface of the LBD (Fig. 6). This helix largely accounts for activation function 2 (AF-2) associated with the LBD, which is ligand dependent. In some NRs, the $\mathrm{A} / \mathrm{B}$ or $\mathrm{N}$-terminal domain (NTD) regions of NRs are associated with an AF-1, which is not dependent on ligand binding and can also assist in the recruitment of coactivators.

Published by Bioscientifica Ltd 
A $\operatorname{PPAR} \alpha+\mathrm{GW} 731$

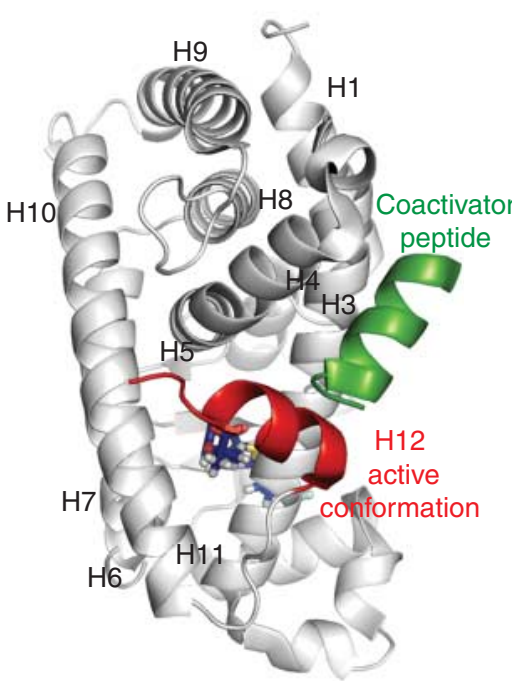

B

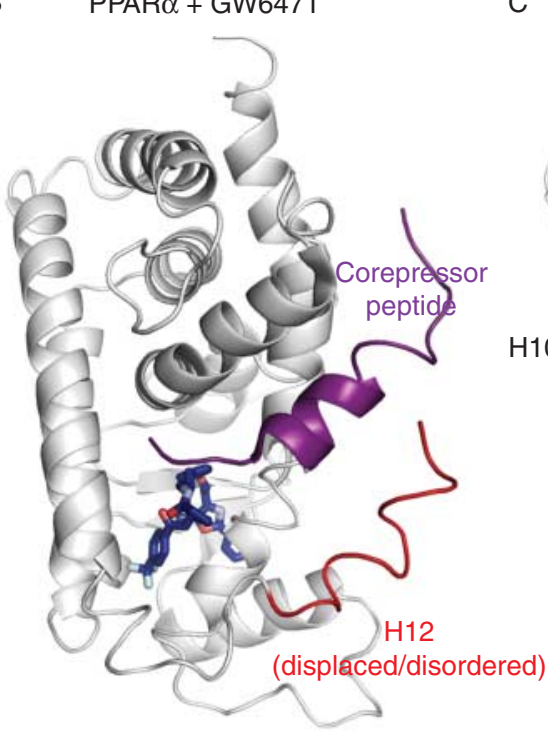

C Rev-Erb $\alpha$ unliganded

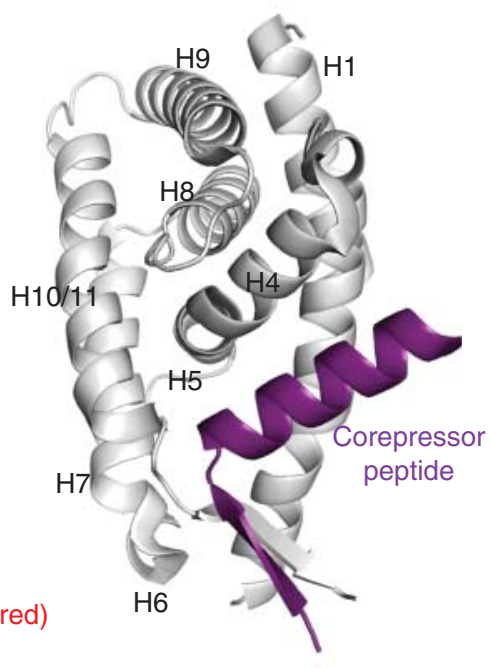

\section{Figure 8}

Comparison of coactivator and corepressor binding modes. (A) The synthetic ligand GW731 is an agonist of PPAR $\alpha$, producing the active conformation and allowing for favorable coactivator binding. (B) In contrast, the synthetic molecule GW6471 displaces helix-12 in this receptor

In the $\mathrm{AR}$, there is evidence for physical interaction between the NTD and LBD that is important for binding of coactivators (He et al. 2000).

Because both coactivators and corepressor recognize LBDs, it is also important to keep in mind the issue of matching the stoichiometry of coregulator binding to dimerization status of NR complexes. Many coactivators and corepressor contain more than one interacting motif within their polypeptides (Heery et al. 1997). In the case of coactivators, proteins such as steroid receptor coactivators contain three or more leucine-rich, LXXLL motifs within a single polypeptide (Heery et al. 1997, Darimont et al. 1998). Similarly, corepressors can possess multiple LXXXLXXX (I/L) motifs, known as CoRNR boxes, within their polypeptides (Hu \& Lazar 1999). We discussed above how NRs can use their DBDs to form DNA-dependent dimerization interfaces. The LBDs too can, in some cases, form LBD-LBD interfaces, doing so independent of DNA as shown in Fig. 5B. Note that LBD-LBD dimerization interfaces form through similar helices, whether one examines RXR heterodimers or the steroid receptor homodimers. As coregulators have multiple leucine-rich motifs, they may attach a single copy of this motif to just one partner of the dimer or use two motifs to contact both NR partners simultaneously. For each of the homodimeric $\mathrm{ERR} \alpha$ or ERR $\gamma$ receptors, an asymmetric coactivator and helps create a stable conformation that allows for a region of the corepressor SMRT to bind onto the surface. (C) The binding of the Rev-Erb $\alpha$ LBD to a corepressor element in the absence of ligand.

binding mode appears to be used, where just one subunit of the homodimeric receptor interacts efficiently with an interacting region from the peroxisome proliferatoractivated receptor $\gamma$ coactivator $1 \alpha(\mathrm{PGC} 1 \alpha)$ protein (Devarakonda et al. 2011, Takacs et al. 2013).

The manner by which most coactivator LXXLL motifs tend to form amphipathic $\alpha$-helices and bind to receptor LBDs in a H12-dependent manner was first seen in the crystal structures of PPAR $\gamma$ and ER (Nolte et al. 1998, Shiau et al. 1998). Those observations have since been revisited in the structures of many other NR LBDs in their active states with LXXLL peptides. In the example provided in Fig. 6, we show how the binding of ROR $\beta$ to an activating ligand (all-trans retinoic acid) leads to a LBD conformation with H12 becoming ordered atop the ligand cavity (Stehlin-Gaon et al. 2003). From this position, H12 physically supports the interactions with the coactivator motif. While the structure of the unligand $\operatorname{ROR} \beta$ is unavailable, one could reasonably infer that due to significant dynamics of H12, LXXLL binding would be prohibited in the apo-state. Figure 6 further shows how facedown interactions of the leucine residues in the LXXLL motif form with respect to a hydrophobic groove on the LBD surface. An accessory clamp mechanism is sometimes used for stabilization of the LXXLL motifs on LBDs. The charge clamp involves the participation of a

Published by Bioscientifica Ltd 
lysine (basic residue) and glutamate (acidic residue) from some LBDs interacting with the dipole of the leucinerich helix (Nolte et al. 1998, Mak et al. 1999, Bledsoe et al. 2002).

Some NR ligands, such as rosiglitazone, are able to directly contact amino acids located on the H12 helix, firmly stabilizing this helix in the active state. But structural studies show that most often ligands indirectly stabilize $\mathrm{H} 12$ through intervening residues, as the pocket is too far from $\mathrm{H} 12$ to allow for the ligand to interact directly (Huang et al. 2010). Synthetic NR ligands have been described with a wide spectrum of activities, comprising full agonists, partial agonists, antagonists, and selective gene modulators. How these molecules shape different receptor activities is not only a consequence of their binding mode but also dependent on the type and ratio of coactivators vs corepressors in a cell type and during a physiological state. Because NRs typically control hundreds or thousands of genes in one or more cell types, the development of receptor agonists or antagonists for therapeutic benefit has proven difficult. A ligand can produce many unintended physiological side effects due to the multitude of gene targets. For this reason, selective modulators are often sought, with the idea that these molecules could control selective gene programs, and not every gene target (Huang et al. 2010). For other disease indications, such as for treatment of breast or prostate cancers that largely depend on the activity of a single NR, potent antagonists may be more acceptable and the development of such compounds has been productive.

Elegant principles for rationally converting a receptor agonist to an antagonist were introduced through the crystallographic characterizations of ERs (Brzozowski et al. 1997, Shiau et al. 1998, Tanenbaum et al. 1998). Those crystallographic studies were then followed by determinations of more ER LBD structures that were in complex with diverse ligands, better advancing our understanding of how agonism, partial agonism, and antagonism are achieved with NRs (Pike et al. 1999, 2000, 2001). As multiple aspects of mammalian growth, differentiation, and reproductive function, as well as heart, bone, and liver physiology are regulated through ER $\alpha$ and ER $\beta$, therapeutic targeting of these receptors was recognized as an important goal for developing breast cancer, osteoporosis, and obesity treatments (Deroo \& Korach 2006).

Figure 7A, B and C illustrate some of the most important lessons unveiled through the early structural studies with both estrogens and synthetic molecules that competed for the endogenous ligand of $\mathrm{ER} \alpha, 17 \beta$-estradiol.
Both estrogen and the synthetic ligand diethylstilbestrol (DES) are agonists causing ERs to be transcriptionally active. As shown in Fig. 7B, these agonists bind inside the LBD cavity and position $\mathrm{H} 12$ in its active conformation. In contrast, molecules such as tamoxifen and raloxifene still use the common DES chemical frame but with the presence of their large, bulky side-chain extension, instead act as ER antagonists, shutting off the transcriptional activity. Tamoxifen has been used widely for clinical treatment of breast cancers. Raloxifene was developed for its protective effects on bone and its antiproliferative effects on breast cancer cells. While most of the key amino acids in the ER pocket responsible for binding these agonists and antagonists are identical, the side-chain extensions of the antagonists point in the direction of $\mathrm{H} 12$ and displace it away from the active position (Fig. 7B and C).

A different set of structural studies shaped our understanding of how corepressors physically interact with NR LBDs. Figure 8A and B show structures of PPAR $\alpha$ with both an agonist (GW731) and an antagonist (GW6471) (Xu et al. 2002, Sierra et al. 2007). The corepressor uses the same location that is occupied by $\mathrm{H} 12$ and the LXXLL motif, when the receptor would be in the activated state. The mutually exclusive binding of these two types of coregulators is an important principle revealed from these crystallographic studies. Another crystallographic characterization of the unliganded Rev-Erb $\alpha$ LBD bound to a N-CoR peptide shows the interactions of a $\beta$-strand together with an $\alpha$-helix from the corepressor (Fig. 8C; Phelan et al. 2010). The occupied position of the corepressor motif is still similar to the binding site of the corepressor motif seen within the PPAR $\alpha$ structure. The two Rev-Erb receptors ( $\alpha$ and $\beta$ ) use heme as their endogenous ligands (Raghuram et al. 2007, Yin et al. 2007, Pardee et al. 2009). Even with heme bound, the Rev-Erbs are not known to interact physiologically with coactivators. Still, a comparison of the heme-bound Rev-Erb $\beta$ with the apo-Rev-Erb $\alpha /$ corepressor complex indicated that heme binding would interfere with the binding of the corepressor motif (Phelan et al. 2010).

Another area that benefited from structural studies has been the discovery of receptor-subtype-selective ligands (Huang et al. 2010, Nilsson et al. 2011). ER $\alpha$ and ER $\beta$ are distinct gene products with non-redundant physiological functions (Gustafsson 2003). ER $\alpha$ and ER $\beta$ regulate different classes of genes by associating with distinct response elements and by recruiting different coregulator complexes (Leitman et al. 2010). Selective modulation of ER activity can be achieved in part through selective

Published by Bioscientifica Ltd 
modulation of one receptor subtype over the other. ER $\alpha$ has been an excellent target for breast cancer therapy using molecules that act as ER antagonists in breast tissue. Agonists could also be potentially valuable for other therapeutic benefits, including osteoporosis, inflammatory, and neurodegenerative diseases (Nilsson et al. 2011). But the activation of ER $\alpha$ imposes an increased risk of the development of breast or endometrial cancer, making agonists more risky for development. ER $\beta$ selective agonists would be advantageous, as they are not expected to stimulate the proliferation of breast or endometrial tissues (Nilsson et al. 2011). But with the two ERs using very similar amino acids in their ligand pocket, can selective ligands really be found? There are seven key amino acids lining the pockets of each receptor and differences in only two of these residues when one compares ER $\alpha$ with ER $\beta$ (leucine vs methionine and methionine vs isoleucine; Huang et al. 2010). Still, a number of molecules have been developed using structure-guided principles that exhibit reasonably selective preference for $\mathrm{ER} \alpha$ over ER $\beta$ (Sun et al. 1999, 2002, Stauffer et al. 2000). Other synthetic molecules have been shown to be selective for ER $\beta$ over ER $\alpha$ (Sun et al. 2003, Manas et al. 2004). A nice example is the molecule diarylpropionitrile (DPN), which acts as an ER $\beta$-selective agonist. Functional assays that relied on ER $\alpha / E R \beta$ chimeras and residue-specific mutagenesis, together with molecular modeling analysis, point to a single residue in the ER pocket (Met 366) as being largely responsible for the ER $\beta$ selectivity of DPN (Sun et al. 2003).

There are other NR subfamilies that consist of multiple members, including the RARs (three RARs) and TRs (two TRs), where subtype selective ligands are sought. While both $\operatorname{TR} \alpha$ and $\operatorname{TR} \beta$ bind to tri-iodothyronine with high
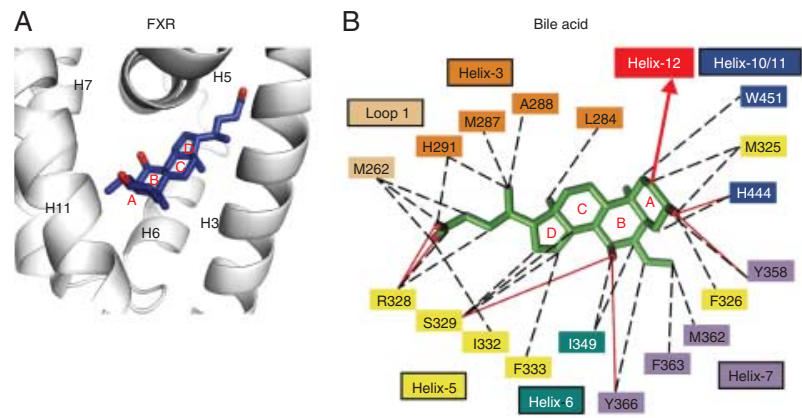

\section{Figure 9}

Demonstration of the distinct orientations of cholesterol-derived ligands in receptor pockets. (A) FXR binding to the bile acid CDCA. (B) Details of interactions with solid red lines indicating hydrogen bonds and dotted lines indicating van der Waals interactions. Note that the steroidal A-ring is affinity, they elicit different physiological responses. TR ligands, aside from their use in thyroid hormone replacement therapy, can potentially be beneficial in lowering serum LDL, cholesterol, and triacylglycerol levels, but only if their other effects on heart, bone, and muscle can be minimized (Baxter \& Webb 2009). Several modulators have been described with four- to tenfold selectivity toward TR $\beta$ over TR $\alpha$ and developed using crystallographic guidance (Wagner et al. 2001). The two TRs have pockets differing in only a single amino acid residue (Huang et al. 2010). In the case of the three RARs, there are three amino acids that differ in the pockets. For RARs also, small molecules that exhibit selective binding to each receptor have been discovered using structure insights (Germain et al. 2004).

While many NRs use steroids and related cholesterolderived molecules as their endogenous ligands, it is worth pointing out how differently these molecules can be oriented and captured within NR-respective pockets. In steroid receptors, the cognate ligands can bind with singledigit nanomolar affinity. In the case of LXRs and FXR, oxysterols and bile acids bind in the micromolar kilodalton range, respectively (Huang et al. 2010). Yet, the ligand affinities of LXR and FXR still match the physiological concentrations of these molecules in tissues such as liver and intestine, making these receptors physiologically responsive. Figure 9 demonstrates how FXR and LXR $\alpha / \beta$, two closely related NRs with a common LBD architecture, orient their related ligands in opposite directions within their pockets. In the case of FXR, the steroid ring A of chenodeoxycholic acid (CDCA) is positioned to point toward H12, whereas in the LXRs, the D-ring and epoxide tail of epoxycholesterol are pointed toward H12 (Mi et al. 2003, Williams et al. 2003).
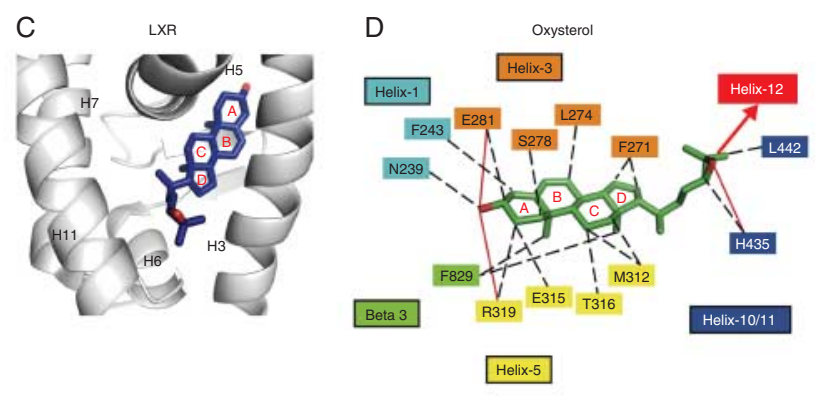

positioned at helix-12 (H12). (C and D) LXR $\alpha$ binding to epoxycholesterol requires the steroidal A-ring to be in the opposite direction, while its side-chain points at $\mathrm{H} 12$.

Published by Bioscientifica Ltd 
This striking difference in ligand recognition points to the incredible diversity and adaptability of NR LBD pockets. There are many examples showing how a single NR pocket can undergo significant readjustment to allow for the binding of various synthetic ligands. We demonstrate this principle with the example shown in Fig. 10. This example shows how the GR pocket accommodates an agonist (dexamethasone) or two significantly larger antagonists using side-chain rearrangements within the pocket (Bledsoe et al. 2002, Kauppi et al. 2003, Biggadike et al. 2008). The GR pocket clearly undergoes induced fit, expanding from a volume of $540 \AA^{3}$ to more than $1000 \AA^{3}$ to make the necessary accommodations for all these ligands. Such findings underscore the plasticity by which a single LBD pocket adapts to ligands with a broad range of chemical scaffolds and functional groups.

\section{Structures of full-length and multi-domain receptor complexes}

Despite multiple DBD-DNA structural characterizations and hundreds of LBD-ligand structural characterizations, there was no reported success in visualizing the higher order architectures of NRs using crystallography until 2008 (Chandra et al. 2008, 2013). For that reason, the physical understanding of how these domains interact and potentially communicate lagged in the field. For other transcription factor families too, visualization of multidomain or complete polypeptides has rarely proved successful by crystallographic means. Also, most structural biologists study the isolated single domains as they tend to crystallize easier. For NRs, several functional and biochemical studies were nevertheless showing us that NR domains were integrated and not like individual beads on a string. In the case of ER, DNA binding at the DBD was shown to alter the ligand-directed activities at the LBD (Hall et al. 2002). The DNA binding in ER could also modulate coactivator binding at the LBD (Hall et al. 2002). In the GR, DNA binding could affect receptor structure and activity at the LBD (Lefstin et al. 1994, Lefstin \& Yamamoto 1998, Meijsing et al. 2009). In the AR, there was also biochemical evidence for DBD communication to the LBD (Helsen et al. 2012). Several synthetic ligands were demonstrated to cause significant changes in the DNA affinity of NRs, even though they bound to the LBD, again suggestive of DBD-LBD communications via domaindomain interactions (Huh et al. 2011, Clegg et al. 2012).

Despite long-standing efforts at visualizing the multidomain arrangements of NRs using high-resolution methods, many technical barriers had remained. First, there is the difficulty in obtaining large quantities of stable, intact proteins in soluble form. Secondly, there are disordered receptor segments, especially when NRs are not in their assembled complexes with DNA and coregulator portions. Thirdly, there is the difficulty in knowing which combination of ligands, peptides, and DNA would produce the stable, well-behaved complex suitable for crystallization. We adopted numerous strategies in attempting to overcome each of these difficulties. These proteins can be obtained through recombinant expression methodologies that employ Escherichia coli, SF-9/baculovirus, or transient transfection
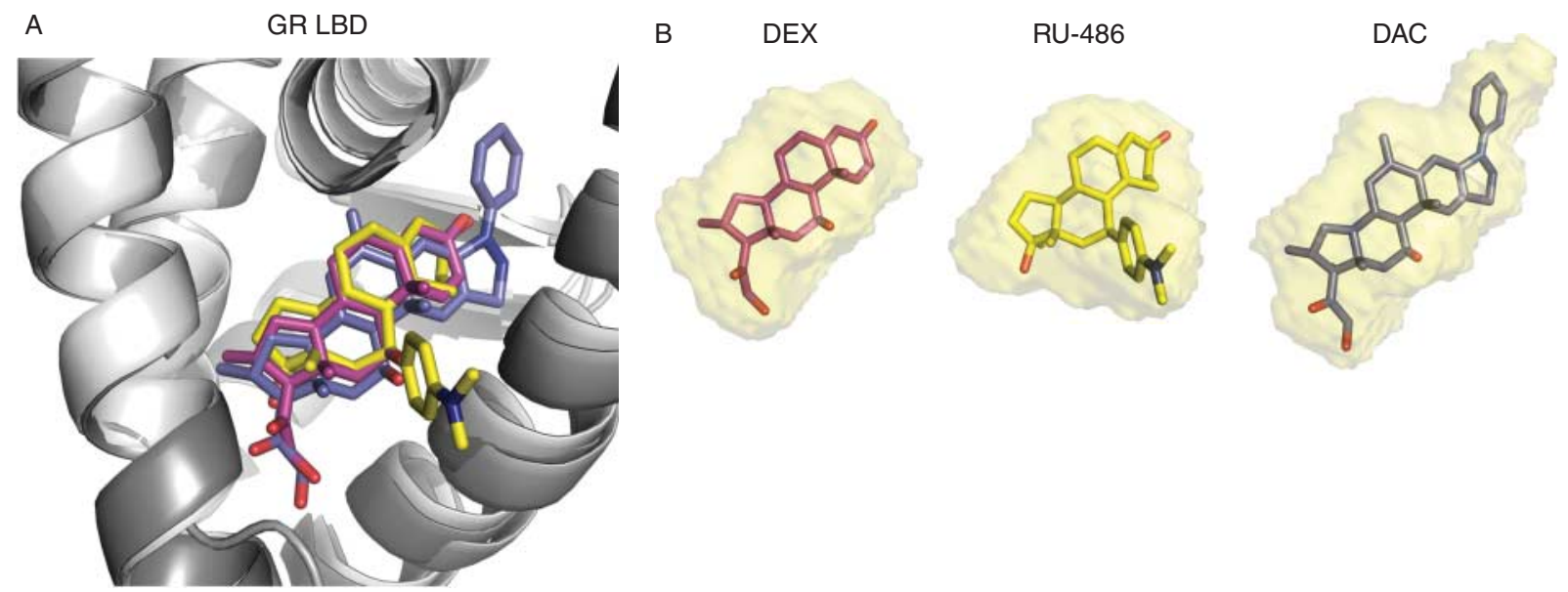

\section{Figure 10}

The LBD pockets can adapt to bind diverse molecules through induced fit. (A) GR LBD with three distinct compounds. (B) The surface volumes of the three ligands occupied in the pocket.

http://jme.endocrinology-journals.org DOI: 10.1530/JME-13-0173
C 2013 Society for Endocrinology Printed in Great Britain
Published by Bioscientifica Ltd 
in HEK-293 or other mammalian cells. Conditions for ensuring the correct folding and maximal solubility of NRs are then identified by testing a battery of receptor ligands for their ability to enhance the soluble protein yield during recombinant expression. To minimize receptor segmental disorder, one can take advantage of H/D EMS information or proteolytic mapping experiments to identify combinations of NRs, ligands, coactivators, and DNA duplexes that produce stable complexes. Finally, size-exclusion chromatography is applied to isolate in a single fraction, the pre-ordered multi-component complexes of NRs. This latter step ensures the correct stoichiometry of components in a single elution peak, which facilitates successful crystal growth.

We first described the complete structural organization and domain couplings of the intact PPAR $\gamma-\operatorname{RXR} \alpha$ heterodimeric complex (Chandra et al. 2008). The complex architecture is shown in Fig. 11 and was crystallized with DR +1 DNA and coactivator LXXLL peptides bound to both receptors, a retinoid molecule bound to $\mathrm{RXR} \alpha$, and several different ligands bound to PPAR $\gamma$ receptor. It became clear that the NR domains were intimately coupled and coordinated, as opposed to being loosely connected and independent domains. A close look at the top panel of Fig. 11 suggests that it is hard to identify the individual domains in the PPAR and RXR receptors, as they are so intertwined. The PPAR $\gamma$ LBD occupies the centerpiece of the entire heterodimeric complex to directly contact all other ordered domains from both RXR $\alpha$ and PPAR $\gamma$ (Fig. 11).

We identified a total of three distinct heterodimerization junctions that had formed between RXR and PPAR, one of which had remained uncharacterized through previous studies utilizing isolated DBDs and LBDs. Therefore, not only were the domains interacting within a single receptor polypeptide but also some domains were interacting across the heterodimeric partners. A number of other striking observations were made: i) two of the three heterodimeric interfaces were controlled by the DNA, ii) the PPAR LBD contributed physically to DNA binding of both PPAR and RXR, iii) the hinge region of PPAR $\gamma$ provided a significant degree of DNA recognition and established the polarity of the complex, and iv) information at the PPAR $\gamma$-LBD (such as ligand or mutations) could in principle be transmitted to the DNA reading heads of the complex, due to domain-domain couplings. The analysis made it clear that discrete DBDs and LBDs could no longer be perceived as self-contained or independently functioning units. In other words, the whole receptor was functionally integrated in ways that were not previously imagined.

Along with many unanticipated findings in the $\operatorname{PPAR} \gamma-\mathrm{RXR} \alpha$ complex, some reconfirmations of past lessons were also revealed. For example, the LBD-LBD interface of the heterodimer involved the same specific contacts previously described by those who crystallized the heterodimeric LBD complex of these two receptors (Nolte et al. 1998). The DBD-DBD interface too looked strikingly similar to the RAR-RXR DBD structure we had previously described on DR1 (Rastinejad et al. 2000). The polarity of the complex on DNA matched the biochemical findings previously predicted, including a role for the CTE in binding to the minor groove of DR1 (Zhao et al. 1998). The insertion of the DNA recognition helix of each receptor in the major grooves of the $5^{\prime}$-AGGTCA-3' also conformed to previously established findings from DBD/DNA structures (Khorasanizadeh \& Rastinejad 2001). The mode of ligand binding and LXXLL peptide binding closely matched what was seen with individual LBD structures previously studied (Nolte et al. 1998). These reconfirmations point to the validity of the full-length crystal structure of the PPAR-RXR and provide confidence in the overall representation described. Moreover, the H/D EMS studies carried out on the full-length PPAR-RXR/DNA complex, as well as mutation analysis of the key domaindomain interfacial junctions, support the crystallographic interpretations of this complex (Chandra et al. 2008).

To study other NR complexes, we next focused on the obligate homodimeric complex of hepatocyte nuclear factor (HNF)- $4 \alpha$ on its cognate DR1 response element. HNF- $4 \alpha$ is the most abundant transcription factor in the liver (Sladek et al. 1990). Targets of this receptor include genes involved in gluconeogenesis and lipid metabolism (Yoon et al. 2001, Bolotin et al. 2010, Fang et al. 2012). In the pancreas, HNF- $4 \alpha$ is believed to control some $11 \%$ of islet genes (Bartoov-Shifman et al. 2002). HNF-4a dysfunction has been linked to a number of pathologies, including metabolic syndrome (Yin et al. 2011). Specific point mutations in the HNF- $4 \alpha$ protein can cause maturity onset of diabetes in the young-1 (MODY1), a monogenic form of diabetes, as well as hyperinsulinemic hypoglycemia, a neonatal disease marked by unregulated insulin secretion with hypoglycemia (Ryffel 2001, Kapoor et al. 2008). As our efforts to crystallize the full-length HNF- $4 \alpha$ proved unsuccessful we instead crystallized and solved the structure of a slightly truncated, multi-component fragment of this receptor with DNA and coactivator peptides.

Our crystallographic findings showed that the HNF-4 $\alpha$ homodimer also used multiple domain-domain

Published by Bioscientifica Ltd 

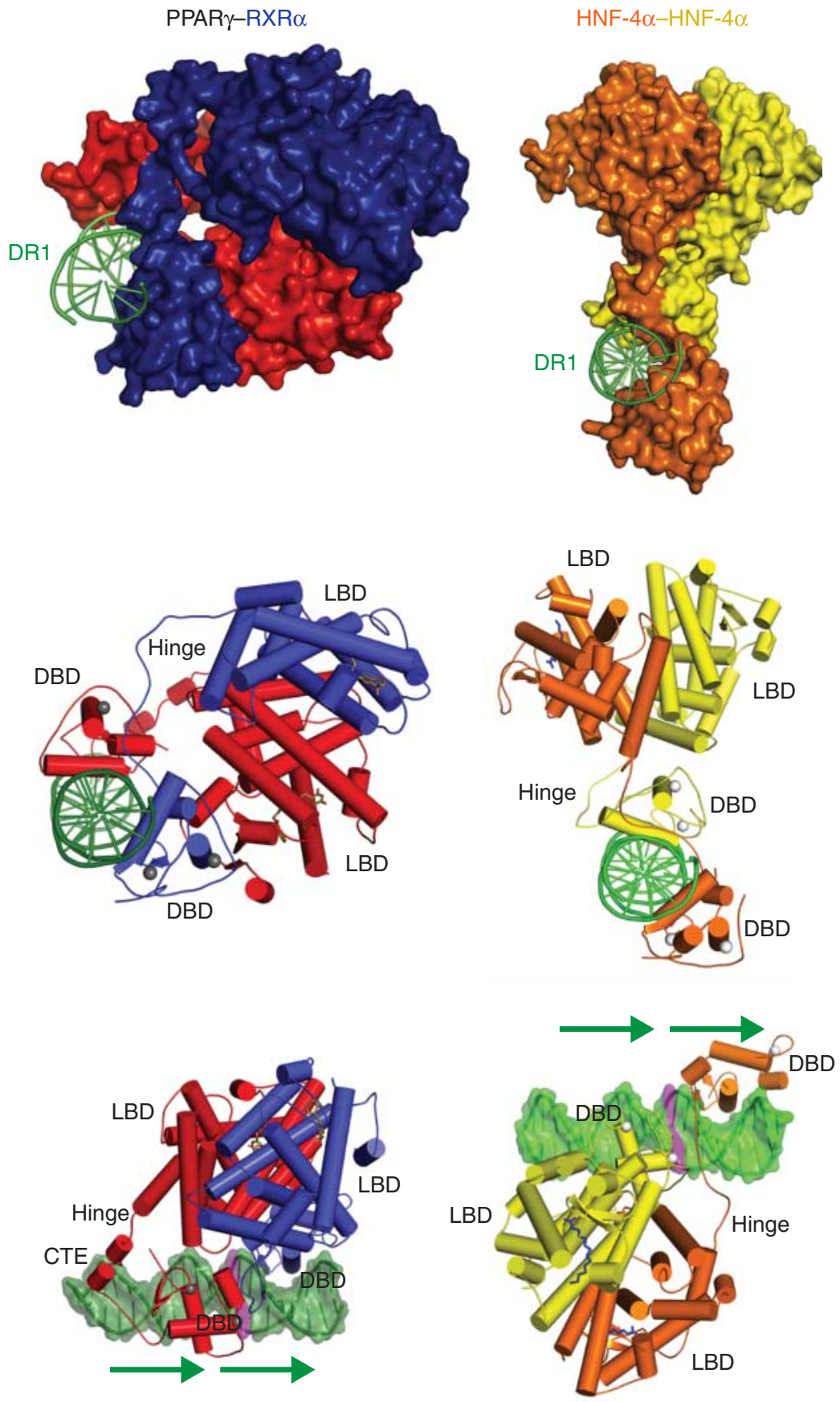

\section{Figure 11}

Crystal structures of multi domain NR complexes. On the left side is the PPAR $\gamma-R X R \alpha$ complex on DR1 and on the right side is the HNF- $4 \alpha$ homodimer on DR1. RXR is indicated in blue and PPAR is indicated in red. The upstream subunit of HNF- $4 \alpha$ is indicated in yellow and the downstream

junctions, integrating its various receptor functions (Fig. 11). A striking convergence zone that we refer to as the 'nerve center' lies at the center of this complex. This is the site where LBDs, the upstream-positioned DBD, and the hinge region of one receptor subunit converge. subunit is indicated in orange. The green arrows show the direction of the AGGTCA direct repeats in the DR1 response elements in the lower panel for both complexes. Three views of each complex are shown.

These connections provide a clear path for signal communications from one end of the complex to the other. The LBDs, which are symmetrical in their mutual interactions, straddle the surface of only the upstream DBD. This arrangement breaks the overall symmetry of the 
heterodimer. The complex is partitioned in the direction of the upstream half site of the DR1 and not symmetrically disposed over the entire DR1. This type of quaternary arrangement favorably allows both DBDs to still engage their AGGTCA half sites and form a productive DNAdependent dimerization interface within the minor groove of the DR1 spacer.

The observed quaternary organization in the HNF- $4 \alpha$ homodimeric complexes also allows both LBD pockets to access and obtain ligands. Both LBD surfaces have exposed coactivator surfaces, where the LXXLL peptides are appropriately bound. Each of the HNF- $4 \alpha$ LBDs has electron density belonging to a trapped fatty acid with 14-16 carbon atoms. The associated fatty acid is believed to be an unusual ligand, providing structural stability to the HNF- $4 \alpha / \gamma$ subfamily and not acting as an activation signal. Fatty acid molecules act in a similar fashion for other NRs, such as SF-1 and LRH-1 (Krylova et al. 2005). Interestingly, HNF- $4 \alpha$ can be regulated by post-translational modifications (PTMs), and no ligand has been decisively shown to regulate all of its transcriptional activities.

Given the closely knit connections between multiple domains in this complex, we used other techniques to explore allosteric communications within the HNF- $4 \alpha$ complex (Chandra et al. 2013). One good test for allosteric communications came from a close look at the MODY1 point mutations. We found that many of these mutations mapped near the 'nerve center, suggesting that their effects could be transmitted from the domain on which they occur, to other distal domains. When we examined the MODY1 mutations positioned on the LBD, we could see that they had a strong effect on the DNA binding affinity of the receptor, even though they were not themselves positioned on the DBD (Chandra et al. 2013). Other mutational changes that we made at the LBD, which were not representative of MODY1 mutations, could still be efficiently communicated to alter the DNA binding affinity, consistent with an allosteric communication system.

A second mode of signal propagation from one domain to another came from the examination of several well-characterized PTMs that had been shown by others to control DNA binding affinity. We found that a methylation site (Arg-91) and a phosphorylation site (Ser-78) could be mapped onto positions directly at the 'nerve center' (Chandra et al. 2013). Consistent with our crystallographic findings, Arg-91 methylation had been known to act as glue to lock-in the active quaternary organization that is capable of high-affinity DNA binding.
Ser-78 phosphorylation was known to cause a loss in DNA binding, and in this structure introduces unfavorable charge repulsion at the nerve center when phosphorylated, so as to disengage the quaternary structure required for efficient DNA binding. Mutational studies further confirmed many of the striking features of the quaternary organization. Fig. 11 shows that the LBDs are participating in DNA binding by firmly holding a DBD atop the DNA. Binding studies confirmed that the LBD containing HNF- $4 \alpha$ polypeptide binds to DR1 with nearly 100-fold better affinity than the DBD alone (Chandra et al. 2013).

A comparison of the PPAR $\gamma-\mathrm{RXR} \alpha$ structure with the HNF- $4 \alpha$ structure demonstrated that these two complexes were forming very different quaternary organizations, even though all the DBDs and LBDs were conserved in folding, and both complexes were bound to the same DR1 response element. We envision that different members of the NR family would also display distinct arrangements of inter-domain junctions, allowing for unique modes of allosteric communications across their polypeptides. Furthermore, while the response element type is important for stabilizing the quaternary organization of the receptors, numerous other factors also drive the overall NR quaternary organization. Sequences and sizes of the hinge regions, as well as the residues on the outside of the LBDs that are not conserved, can participate in producing unique quaternary architectures for each NR complex.

We also found in both complexes that the NTDs were not observed, due to a lack of structural order or failure to interact with other receptor segments. The NTD portions have been shown to be functionally important for gene activation in some receptors, but have consistently failed to show structural order when examined alone or in the context of entire polypeptides. Invoking the concept of induced folding, it is possible that A/B segments become folded only upon interactions with specific coregulators that assemble in the active or repressed complexes. The H/D EMS study carried out on the PPAR A/B domain, alone and in the presence of its dimeric partner RXR and DNA, also failed to find ordered regions.

While crystallography has so far proven the most powerful tool for visualizing the physical molecular interactions in full-length NRs, electron microscopy and solution biophysical methods are also adding lowresolution (10-30 A resolution) information (Rochel et al. 2011, Orlov et al. 2012). These studies provide information in terms of broad molecular envelopes that can help one to position well-ordered domains relative to each other. But due to their far lower resolution, such studies cannot

Published by Bioscientifica Ltd 
reveal the basis for allosteric communications in a NR complex. H/D EMS can provide more specific information regarding allostery and signal propagation from one domain to another. A study carried out on the VDR-RXR full-length receptor complex has successfully uncovered how DNA binding alters receptor dynamics in regions far from the DBDs, including the coregulator binding surfaces of both receptors (Zhang et al. 2011). Future studies based on high-resolution structure characterizations combined with dynamics information will continue to show how interfacial surfaces in other NR complexes allow signals to be communicated allosterically across receptor complexes.

\section{Conclusions}

As major transcriptional regulators controlling development, endocrine signaling, metabolism, and circadian rhythms, the NR polypeptides are remarkably efficient at integrating small-molecule binding with DNA interactions and transcriptional regulation. This view suggests that NRs must indeed have integrated domains that communicate information from one part of their polypeptides to another. Until recently, all previous structural efforts were more focused and successful with individual DBDs and LBDs. Through those studies, we have come to appreciate importance of both specificity and induced fit afforded by these domains. Moreover, the structural studies with LBDs provided rational guidance for ligand discovery and optimization. Multiple types of synthetic ligands were successfully produced for NR LBDs, with these molecules capable of evoking a range of physiological responses ranging from full antagonism to full agonism. Structural biology has provided the field with both the language and visual understanding for how DNA, ligand, and coregulator interactions are achieved within the constraints of single receptor domains.

At the same time, the intensive use of isolated fragments slowed the field from fully appreciating the likelihood and consequences of domain-domain communications. A small perturbation, such as base pair difference between two response elements sensed by the DBDs, a disease mutation, a PTM, or a switch in ligand type at the LBD, could manifest itself by changing the function elsewhere within NR polypeptides. The two current crystal structures of multi-domain complexes of NRs demonstrate distinct and alluring types of domain-domain interfaces, providing important lessons about the consequences of quaternary organization in NR architectures. Given the multitude of macromolecular interactions required for NR function in physiological settings, there is still much to be discovered about the physical and functional principles that govern signal propagation in these receptors.

In recognizing the importance of domain-domain connections in NR complexes, one can begin to consider designing allosteric ligands that do not just change coregulator affinities at the LBD in the way of conventional ligands but that instead alter DNA affinity, response element selectivity, or receptor regulation by PTMs. Many synthetic NR ligands have already been discovered using the classic screening strategies that rely on NRs LBDs but rarely have such molecules proven to be selective modulators with gene-specific actions. Understanding the precise details of allosteric communications and domain-domain connections should help enhance success in identifying NR ligands with more desirable and specific actions. Indeed, allosteric modulators for other protein classes have been discovered, and success in finding allosteric molecules for NRs will be enhanced when appropriate screening strategies are employed that fully exploit the structural information emerging for fulllength NR complexes.

\section{Declaration of interest}

The authors declare that there is no conflict of interest that could be perceived as prejudicing the impartiality of the review reported.

\section{Funding}

This work was supported by National Institutes of Health grant number R01 DK094147.

\section{References}

Bartoov-Shifman R, Hertz R, Wang H, Wollheim CB, Bar-Tana J \& Walker MD 2002 Activation of the insulin gene promoter through a direct effect of hepatocyte nuclear factor $4 \alpha$. Journal of Biological Chemistry 277 25914-25919. (doi:10.1074/jbc.M201582200)

Baxter JD \& Webb P 2009 Thyroid hormone mimetics: potential applications in atherosclerosis, obesity and type 2 diabetes. Nature Reviews. Drug Discovery 8 308-320. (doi:10.1038/nrd2830)

Biggadike K, Bledsoe RK, Hassell AM, Kirk BE, McLay IM, Shewchuk LM \& Stewart EL 2008 X-ray crystal structure of the novel enhanced-affinity glucocorticoid agonist fluticasone furoate in the glucocorticoid receptor-ligand binding domain. Journal of Medicinal Chemistry $\mathbf{5 1}$ 3349-3352. (doi:10.1021/jm800279t)

Bledsoe RK, Montana VG, Stanley TB, Delves CJ, Apolito CJ, McKee DD, Consler TG, Parks DJ, Stewart EL, Willson TM et al. 2002 Crystal structure of the glucocorticoid receptor ligand binding domain reveals a novel mode of receptor dimerization and coactivator recognition. Cell 110 93-105. (doi:10.1016/S0092-8674(02)00817-6)

Bolotin E, Liao H, Ta TC, Yang C, Hwang-Verslues W, Evans JR, Jiang T \& Sladek FM 2010 Integrated approach for the identification of human hepatocyte nuclear factor $4 \alpha$ target genes using protein binding microarrays. Hepatology 51 642-653. (doi:10.1002/hep.23357) http://jme.endocrinology-journals.org DOI: 10.1530/JME-13-0173
(C) 2013 Society for Endocrinology Printed in Great Britain
Published by Bioscientifica Ltd 
Bourguet W, Ruff M, Chambon P, Gronemeyer H \& Moras D 1995 Crystal structure of the ligand-binding domain of the human nuclear receptor RXR- $\alpha$. Nature 375 377-382. (doi:10.1038/375377a0)

Bruning JB, Chalmers MJ, Prasad S, Busby SA, Kamenecka TM, He Y, Nettles KW \& Griffin PR 2007 Partial agonists activate PPAR $\gamma$ using a helix 12 independent mechanism. Structure 15 1258-1271. (doi:10.1016/j.str.2007.07.014)

Brzozowski AM, Pike AC, Dauter Z, Hubbard RE, Bonn T, Engstrom O, Ohman L, Greene GL, Gustafsson JA \& Carlquist M 1997 Molecular basis of agonism and antagonism in the oestrogen receptor. Nature 389 753-758. (doi:10.1038/39645)

Bugge TH, Pohl J, Lonnoy O \& Stunnenberg HG $1992 \mathrm{RXR} \alpha$, a promiscuous partner of retinoic acid and thyroid hormone receptors. EMBO Journal 11 1409-1418.

Chandra V, Huang P, Hamuro Y, Raghuram S, Wang Y, Burris TP \& Rastinejad F 2008 Structure of the intact PPAR- $\gamma-$ RXR- $\alpha$ nuclear receptor complex on DNA. Nature $\mathbf{4 5 6}$ 350-356. (doi:10.1038/ nature07413)

Chandra V, Huang P, Potluri N, Wu D, Kim Y \& Rastinejad F 2013 Multidomain integration in the structure of the HNF- $4 \alpha$ nuclear receptor complex. Nature 495 394-398. (doi:10.1038/nature11966)

Charles JP, Shinoda T \& Chinzei Y 1999 Characterization and DNA-binding properties of GRF, a novel monomeric binding orphan receptor related to GCNF and BFTZ-F1. European Journal of Biochemistry 266 181-190. (doi:10.1046/j.1432-1327.1999.00842.x)

Clegg NJ, Wongvipat J, Joseph JD, Tran C, Ouk S, Dilhas A, Chen Y, Grillot K, Bischoff ED, Cai L et al. 2012 ARN-509: a novel antiandrogen for prostate cancer treatment. Cancer Research 72 1494-1503. (doi:10.1158/00085472.CAN-11-3948)

Dai SY, Burris TP, Dodge JA, Montrose-Rafizadeh C, Wang Y, Pascal BD, Chalmers MJ \& Griffin PR 2009 Unique ligand binding patterns between estrogen receptor $\alpha$ and $\beta$ revealed by hydrogen-deuterium exchange. Biochemistry 48 9668-9676. (doi:10.1021/bi901149t)

Darimont BD, Wagner RL, Apriletti JW, Stallcup MR, Kushner PJ, Baxter JD, Fletterick RJ \& Yamamoto KR 1998 Structure and specificity of nuclear receptor-coactivator interactions. Genes and Development 12 3343-3356. (doi:10.1101/gad.12.21.3343)

Deroo BJ \& Korach KS 2006 Estrogen receptors and human disease. Journal of Clinical Investigation 116 561-570. (doi:10.1172/JCI27987)

Devarakonda S, Harp JM, Kim Y, Ozyhar A \& Rastinejad F 2003 Structure of the heterodimeric ecdysone receptor DNA-binding complex. EMBO Journal 22 5827-5840. (doi:10.1093/emboj/cdg569)

Devarakonda S, Gupta K, Chalmers MJ, Hunt JF, Griffin PR, Van Duyne GD \& Spiegelman BM 2011 Disorder-to-order transition underlies the structural basis for the assembly of a transcriptionally active PGC$1 \alpha /$ ERR $\gamma$ complex. PNAS 108 18678-18683. (doi:10.1073/pnas. 1113813108)

Fang B, Mane-Padros D, Bolotin E, Jiang T \& Sladek FM 2012 Identification of a binding motif specific to HNF4 by comparative analysis of multiple nuclear receptors. Nucleic Acids Research 40 5343-5356. (doi:10.1093/ nar/gks190)

Forman BM, Umesono K, Chen J \& Evans RM 1995 Unique response pathways are established by allosteric interactions among nuclear hormone receptors. Cell 81 541-550. (doi:10.1016/0092-8674 (95)90075-6)

Freedman LP, Luisi BF, Korszun ZR, Basavappa R, Sigler PB \& Yamamoto KR 1988 The function and structure of the metal coordination sites within the glucocorticoid receptor DNA binding domain. Nature 334 543-546. (doi:10.1038/334543a0)

Germain P, Iyer J, Zechel C \& Gronemeyer H 2002 Co-regulator recruitment and the mechanism of retinoic acid receptor synergy. Nature 415 187-192. (doi:10.1038/415187a)

Germain P, Kammerer S, Perez E, Peluso-Iltis C, Tortolani D, Zusi FC, Starrett J, Lapointe P, Daris JP, Marinier A et al. 2004 Rational design of RAR-selective ligands revealed by RAR $\beta$ crystal structure. EMBO Reports 5 877-882. (doi:10.1038/sj.embor.7400235)
Giguere V, McBroom LD \& Flock G 1995 Determinants of target gene specificity for ROR $\alpha 1$ : monomeric DNA binding by an orphan nuclear receptor. Molecular and Cellular Biology 15 2517-2526.

Glass CK \& Rosenfeld MG 2000 The coregulator exchange in transcriptional functions of nuclear receptors. Genes and Development 14 121-141. (doi:10.1101/gad.14.2.121)

Green S \& Chambon P 1987 Oestradiol induction of a glucocorticoidresponsive gene by a chimaeric receptor. Nature 325 75-78. (doi:10.1038/325075a0)

Greschik H, Wurtz JM, Sanglier S, Bourguet W, van Dorsselaer A, Moras D \& Renaud JP 2002 Structural and functional evidence for ligandindependent transcriptional activation by the estrogen-related receptor 3 . Molecular Cell 9 303-313. (doi:10.1016/S1097-2765(02)00444-6)

Gronemeyer H, Gustafsson JA \& Laudet V 2004 Principles for modulation of the nuclear receptor superfamily. Nature Reviews. Drug Discovery 3 950-964. (doi:10.1038/nrd1551)

Gustafsson JA 2003 What pharmacologists can learn from recent advances in estrogen signalling. Trends in Pharmacological Sciences 24 479-485. (doi:10.1016/S0165-6147(03)00229-3)

Hall JM, McDonnell DP \& Korach KS 2002 Allosteric regulation of estrogen receptor structure, function, and coactivator recruitment by different estrogen response elements. Molecular Endocrinology 16 469-486. (doi:10.1210/me.16.3.469)

Hallenbeck PL, Marks MS, Lippoldt RE, Ozato K \& Nikodem VM 1992 Heterodimerization of thyroid hormone (TH) receptor with H-2RIIBP (RXR $\beta$ ) enhances DNA binding and TH-dependent transcriptional activation. PNAS 89 5572-5576. (doi:10.1073/pnas.89.12.5572)

Hard T, Kellenbach E, Boelens R, Maler BA, Dahlman K, Freedman LP, Carlstedt-Duke J, Yamamoto KR, Gustafsson JA \& Kaptein R 1990 Solution structure of the glucocorticoid receptor DNA-binding domain. Science 249 157-160. (doi:10.1126/science.2115209)

Harding HP \& Lazar MA 1995 The monomer-binding orphan receptor Rev-Erb represses transcription as a dimer on a novel direct repeat. Molecular and Cellular Biology 15 4791-4802.

He B, Kemppainen JA \& Wilson EM 2000 FXXLF and WXXLF sequences mediate the $\mathrm{NH} 2$-terminal interaction with the ligand binding domain of the androgen receptor. Journal of Biological Chemistry 275 22986-22994. (doi:10.1074/jbc.M002807200)

Heery DM, Kalkhoven E, Hoare S \& Parker MG 1997 A signature motif in transcriptional co-activators mediates binding to nuclear receptors. Nature 387 733-736. (doi:10.1038/42750)

Helsen C, Dubois V, Verfaillie A, Young J, Trekels M, Vancraenenbroeck R, De Maeyer M \& Claessens F 2012 Evidence for DNA-binding domain - ligand-binding domain communications in the androgen receptor. Molecular and Cellular Biology 32 3033-3043. (doi:10.1128/MCB.00151-12)

Hu X \& Lazar MA 1999 The CoRNR motif controls the recruitment of corepressors by nuclear hormone receptors. Nature $\mathbf{4 0 2}$ 93-96. (doi:10.1038/47069)

Huang P, Chandra V \& Rastinejad F 2010 Structural overview of the nuclear receptor superfamily: insights into physiology and therapeutics. Annual Review of Physiology 72 247-272. (doi:10.1146/annurevphysiol-021909-135917)

Hughes TS, Chalmers MJ, Novick S, Kuruvilla DS, Chang MR, Kamenecka TM, Rance M, Johnson BA, Burris TP, Griffin PR et al. 2012 Ligand and receptor dynamics contribute to the mechanism of graded PPAR $\gamma$ agonism. Structure 20 139-150. (doi:10.1016/j.str.2011.10.018)

Huh JR, Leung MW, Huang P, Ryan DA, Krout MR, Malapaka RR, Chow J, Manel N, Ciofani M, Kim SV et al. 2011 Digoxin and its derivatives suppress TH17 cell differentiation by antagonizing ROR $\gamma \mathrm{t}$ activity. Nature 472 486-490. (doi:10.1038/nature09978)

Johnson BA, Wilson EM, Li Y, Moller DE, Smith RG \& Zhou G 2000 Ligand-induced stabilization of PPAR $\gamma$ monitored by NMR spectroscopy: implications for nuclear receptor activation. Journal of Molecular Biology 298 187-194. (doi:10.1006/jmbi.2000.3636) 
Kallenberger BC, Love JD, Chatterjee VK \& Schwabe JW 2003 A dynamic mechanism of nuclear receptor activation and its perturbation in a human disease. Nature Structural Biology 10 136-140. (doi:10.1038/ nsb892)

Kapoor RR, Locke J, Colclough K, Wales J, Conn JJ, Hattersley AT, Ellard S \& Hussain K 2008 Persistent hyperinsulinemic hypoglycemia and maturity-onset diabetes of the young due to heterozygous HNF4A mutations. Diabetes 57 1659-1663. (doi:10.2337/db07-1657)

Kauppi B, Jakob C, Farnegardh M, Yang J, Ahola H, Alarcon M, Calles K, Engstrom O, Harlan J, Muchmore S et al. 2003 The three-dimensional structures of antagonistic and agonistic forms of the glucocorticoid receptor ligand-binding domain: RU-486 induces a transconformation that leads to active antagonism. Journal of Biological Chemistry $\mathbf{2 7 8}$ 22748-22754. (doi:10.1074/jbc.M212711200)

Keidel S, LeMotte P \& Apfel C 1994 Different agonist- and antagonistinduced conformational changes in retinoic acid receptors analyzed by protease mapping. Molecular and Cellular Biology 14 287-298.

Khorasanizadeh S \& Rastinejad F 2001 Nuclear-receptor interactions on DNA-response elements. Trends in Biochemical Sciences 26 384-390. (doi:10.1016/S0968-0004(01)01800-X)

Kliewer SA, Umesono K, Mangelsdorf DJ \& Evans RM 1992a Retinoid X receptor interacts with nuclear receptors in retinoic acid, thyroid hormone and vitamin D3 signalling. Nature 355 446-449. (doi:10.1038/355446a0)

Kliewer SA, Umesono K, Noonan DJ, Heyman RA \& Evans RM 1992b Convergence of 9-cis retinoic acid and peroxisome proliferator signalling pathways through heterodimer formation of their receptors. Nature 358 771-774. (doi:10.1038/358771a0)

Knegtel RM, Katahira M, Schilthuis JG, Bonvin AM, Boelens R, Eib D, van der Saag PT \& Kaptein R 1993 The solution structure of the human retinoic acid receptor- $\beta$ DNA-binding domain. Journal of Biomolecular NMR 3 1-17. (doi:10.1007/BF00242472)

Kruse SW, Suino-Powell K, Zhou XE, Kretschman JE, Reynolds R, Vonrhein C, Xu Y, Wang L, Tsai SY, Tsai MJ et al. 2008 Identification of COUP-TFII orphan nuclear receptor as a retinoic acid-activated receptor. PLoS Biology 6 e227. (doi:10.1371/journal.pbio.0060227)

Krylova IN, Sablin EP, Moore J, Xu RX, Waitt GM, MacKay JA, Juzumiene D, Bynum JM, Madauss K, Montana V et al. 2005 Structural analyses reveal phosphatidyl inositols as ligands for the NR5 orphan receptors SF-1 and LRH-1. Cell 120 343-355. (doi:10.1016/j.cell.2005.01.024)

Kumar V, Green S, Stack G, Berry M, Jin JR \& Chambon P 1987 Functional domains of the human estrogen receptor. Cell 51 941-951. (doi:10.1016/0092-8674(87)90581-2)

Kurokawa R, DiRenzo J, Boehm M, Sugarman J, Gloss B, Rosenfeld MG, Heyman RA \& Glass CK 1994 Regulation of retinoid signalling by receptor polarity and allosteric control of ligand binding. Nature $\mathbf{3 7 1}$ 528-531. (doi:10.1038/371528a0)

Lefstin JA \& Yamamoto KR 1998 Allosteric effects of DNA on transcriptional regulators. Nature 392 885-888. (doi:10.1038/31860)

Lefstin JA, Thomas JR \& Yamamoto KR 1994 Influence of a steroid receptor DNA-binding domain on transcriptional regulatory functions. Genes and Development 8 2842-2856. (doi:10.1101/gad.8.23.2842)

Leid M, Kastner P, Lyons R, Nakshatri H, Saunders M, Zacharewski T, Chen JY, Staub A, Garnier JM, Mader S et al. 1992 Purification, cloning, and RXR identity of the HeLa cell factor with which RAR or TR heterodimerizes to bind target sequences efficiently. Cell 68 377-395. (doi:10.1016/0092-8674(92)90478-U)

Leitman DC, Paruthiyil S, Vivar OI, Saunier EF, Herber CB, Cohen I, Tagliaferri M \& Speed TP 2010 Regulation of specific target genes and biological responses by estrogen receptor subtype agonists. Current Opinion in Pharmacology 10 629-636. (doi:10.1016/j.coph.2010.09.009)

Leng X, Tsai SY, O'Malley BW \& Tsai MJ 1993 Ligand-dependent conformational changes in thyroid hormone and retinoic acid receptors are potentially enhanced by heterodimerization with retinoic $\mathrm{X}$ receptor. Journal of Steroid Biochemistry and Molecular Biology 46 643-661. (doi:10.1016/0960-0760(93)90306-H)
Li Y, Lambert MH \& Xu HE 2003 Activation of nuclear receptors: a perspective from structural genomics. Structure 11 741-746. (doi:10.1016/S0969-2126(03)00133-3)

Little TH, Zhang Y, Matulis CK, Weck J, Zhang Z, Ramachandran A, Mayo KE \& Radhakrishnan I 2006 Sequence-specific deoxyribonucleic acid (DNA) recognition by steroidogenic factor 1: a helix at the carboxy terminus of the DNA binding domain is necessary for complex stability. Molecular Endocrinology 20 831-843. (doi:10.1210/me.2005-0384)

Lu P, Rha GB, Melikishvili M, Wu G, Adkins BC, Fried MG \& Chi YI 2008 Structural basis of natural promoter recognition by a unique nuclear receptor, HNF4 $\alpha$. Diabetes gene product. Journal of Biological Chemistry 283 33685-33697. (doi:10.1074/jbc.M806213200)

Luisi BF, Xu WX, Otwinowski Z, Freedman LP, Yamamoto KR \& Sigler PB 1991 Crystallographic analysis of the interaction of the glucocorticoid receptor with DNA. Nature 352 497-505. (doi:10.1038/352497a0)

Mader S, Chen JY, Chen Z, White J, Chambon P \& Gronemeyer H 1993 The patterns of binding of RAR, RXR and TR homo- and heterodimers to direct repeats are dictated by the binding specificites of the DNA binding domains. EMBO Journal 12 5029-5041.

Mak HY, Hoare S, Henttu PM \& Parker MG 1999 Molecular determinants of the estrogen receptor-coactivator interface. Molecular and Cellular Biology 19 3895-3903.

Manas ES, Unwalla RJ, Xu ZB, Malamas MS, Miller CP, Harris HA, Hsiao C, Akopian T, Hum WT, Malakian K et al. 2004 Structure-based design of estrogen receptor- $\beta$ selective ligands. Journal of the American Chemical Society 126 15106-15119. (doi:10.1021/ja0476330)

Mangelsdorf DJ \& Evans RM 1995 The RXR heterodimers and orphan receptors. Cell 83 841-850. (doi:10.1016/0092-8674(95)90200-7)

Mangelsdorf DJ, Thummel C, Beato M, Herrlich P, Schutz G, Umesono K, Blumberg B, Kastner P, Mark M, Chambon P et al. 1995 The nuclear receptor superfamily: the second decade. Cell 83 835-839. (doi:10.1016/0092-8674(95)90199-X)

Marks MS, Hallenbeck PL, Nagata T, Segars JH, Appella E, Nikodem VM \& Ozato K 1992 H-2RIIBP (RXR $\beta$ ) heterodimerization provides a mechanism for combinatorial diversity in the regulation of retinoic acid and thyroid hormone responsive genes. EMBO Journal 11 1419-1435.

McKenna NJ, Lanz RB \& O'Malley BW 1999 Nuclear receptor coregulators: cellular and molecular biology. Endocrine Reviews 20 321-344. (doi:10.1210/er.20.3.321)

Meijsing SH, Pufall MA, So AY, Bates DL, Chen L \& Yamamoto KR 2009 DNA binding site sequence directs glucocorticoid receptor structure and activity. Science 324 407-410. (doi:10.1126/science.1164265)

Meinke G \& Sigler PB 1999 DNA-binding mechanism of the monomeric orphan nuclear receptor NGFI-B. Nature Structural Biology 6 471-477. (doi:10.1038/8276)

Mi LZ, Devarakonda S, Harp JM, Han Q, Pellicciari R, Willson TM, Khorasanizadeh S \& Rastinejad F 2003 Structural basis for bile acid binding and activation of the nuclear receptor FXR. Molecular Cell $\mathbf{1 1}$ 1093-1100. (doi:10.1016/S1097-2765(03)00112-6)

Mukherjee R, Davies PJ, Crombie DL, Bischoff ED, Cesario RM, Jow L, Hamann LG, Boehm MF, Mondon CE, Nadzan AM et al. 1997 Sensitization of diabetic and obese mice to insulin by retinoid $\mathrm{X}$ receptor agonists. Nature 386 407-410. (doi:10.1038/386407a0)

Nagy L \& Schwabe JW 2004 Mechanism of the nuclear receptor molecular switch. Trends in Biochemical Sciences 29 317-324. (doi:10.1016/j.tibs. 2004.04.006)

Nelson CC, Hendy SC, Shukin RJ, Cheng H, Bruchovsky N, Koop BF \& Rennie PS 1999 Determinants of DNA sequence specificity of the androgen, progesterone, and glucocorticoid receptors: evidence for differential steroid receptor response elements. Molecular Endocrinology 13 2090-2107. (doi:10.1210/me.13.12.2090)

Nilsson S, Koehler KF \& Gustafsson JA 2011 Development of subtypeselective oestrogen receptor-based therapeutics. Nature Reviews. Drug Discovery 10 778-792. (doi:10.1038/nrd3551) 
Nolte RT, Wisely GB, Westin S, Cobb JE, Lambert MH, Kurokawa R, Rosenfeld MG, Willson TM, Glass CK \& Milburn MV 1998 Ligand binding and co-activator assembly of the peroxisome proliferatoractivated receptor- $\gamma$. Nature 395 137-143. (doi:10.1038/25931)

Orlov I, Rochel N, Moras D \& Klaholz BP 2012 Structure of the full human RXR/VDR nuclear receptor heterodimer complex with its DR3 target DNA. EMBO Journal 31 291-300. (doi:10.1038/emboj.2011.445)

Ottow E \& Weinmann H 2008 Nuclear Receptors as Drug Targets. Weinheim, Germany: Wiley-VCH.

Pardee KI, Xu X, Reinking J, Schuetz A, Dong A, Liu S, Zhang R, Tiefenbach J, Lajoie G, Plotnikov AN et al. 2009 The structural basis of gas-responsive transcription by the human nuclear hormone receptor REV-ERB $\beta$. PLoS Biology 7 e43. (doi:10.1371/journal.pbio.1000043)

Perlmann T, Rangarajan PN, Umesono K \& Evans RM 1993 Determinants for selective RAR and TR recognition of direct repeat HREs. Genes and Development 7 1411-1422. (doi:10.1101/gad.7.7b.1411)

Phelan CA, Gampe RT Jr, Lambert MH, Parks DJ, Montana V, Bynum J, Broderick TM, Hu X, Williams SP, Nolte RT et al. 2010 Structure of Rev-erb $\alpha$ bound to N-CoR reveals a unique mechanism of nuclear receptor-co-repressor interaction. Nature Structural \& Molecular Biology 17 808-814. (doi:10.1038/nsmb.1860)

Pike AC, Brzozowski AM, Hubbard RE, Bonn T, Thorsell AG, Engstrom O, Ljunggren J, Gustafsson JA \& Carlquist M 1999 Structure of the ligand-binding domain of oestrogen receptor $\beta$ in the presence of a partial agonist and a full antagonist. EMBO Journal $184608-4618$ (doi:10.1093/emboj/18.17.4608)

Pike AC, Brzozowski AM, Walton J, Hubbard RE, Bonn T, Gustafsson JA \& Carlquist M 2000 Structural aspects of agonism and antagonism in the oestrogen receptor. Biochemical Society Transactions 28 396-400. (doi:10.1042/0300-5127:0280396)

Pike AC, Brzozowski AM, Walton J, Hubbard RE, Thorsell AG, Li YL, Gustafsson JA \& Carlquist M 2001 Structural insights into the mode of action of a pure antiestrogen. Structure 9 145-153. (doi:10.1016/ S0969-2126(01)00568-8)

Pissios P, Tzameli I, Kushner P \& Moore DD 2000 Dynamic stabilization of nuclear receptor ligand binding domains by hormone or corepressor binding. Molecular Cell 6 245-253. (doi:10.1016/ S1097-2765(00)00026-5)

Raghuram S, Stayrook KR, Huang P, Rogers PM, Nosie AK, McClure DB, Burris LL, Khorasanizadeh S, Burris TP \& Rastinejad F 2007 Identification of heme as the ligand for the orphan nuclear receptors REV-ERB $\alpha$ and REV-ERBß. Nature Structural \& Molecular Biology 14 1207-1213. (doi:10.1038/nsmb1344)

Rastinejad F, Perlmann T, Evans RM \& Sigler PB 1995 Structural determinants of nuclear receptor assembly on DNA direct repeats. Nature 375 203-211. (doi:10.1038/375203a0)

Rastinejad F, Wagner T, Zhao Q \& Khorasanizadeh S 2000 Structure of the RXR-RAR DNA-binding complex on the retinoic acid response element DR1. EMBO Journal 19 1045-1054. (doi:10.1093/emboj/19.5.1045)

Renaud JP, Rochel N, Ruff M, Vivat V, Chambon P, Gronemeyer H \& Moras D 1995 Crystal structure of the RAR- $\gamma$ ligand-binding domain bound to all-trans retinoic acid. Nature 378 681-689. (doi:10.1038/378681a0)

Rochel N, Ciesielski F, Godet J, Moman E, Roessle M, Peluso-Iltis C, Moulin M, Haertlein M, Callow P, Mely Y et al. 2011 Common architecture of nuclear receptor heterodimers on DNA direct repeat elements with different spacings. Nature Structural \& Molecular Biology 18 564-570. (doi:10.1038/nsmb.2054)

Roemer SC, Donham DC, Sherman L, Pon VH, Edwards DP \& Churchill ME 2006 Structure of the progesterone receptor-deoxyribonucleic acid complex: novel interactions required for binding to half-site response elements. Molecular Endocrinology 20 3042-3052. (doi:10.1210/me. 2005-0511)

Ryffel GU 2001 Mutations in the human genes encoding the transcription factors of the hepatocyte nuclear factor (HNF)1 and HNF4 families: functional and pathological consequences. Journal of Molecular Endocrinology 27 11-29. (doi:10.1677/jme.0.0270011)
Sablin EP, Krylova IN, Fletterick RJ \& Ingraham HA 2003 Structural basis for ligand-independent activation of the orphan nuclear receptor LRH-1. Molecular Cell 11 1575-1585. (doi:10.1016/S1097-2765(03)00236-3)

Schwabe JW, Neuhaus D \& Rhodes D 1990 Solution structure of the DNAbinding domain of the oestrogen receptor. Nature 348 458-461. (doi:10.1038/348458a0)

Schwabe JW, Chapman L, Finch JT \& Rhodes D 1993 The crystal structure of the estrogen receptor DNA-binding domain bound to DNA: how receptors discriminate between their response elements. Cell $\mathbf{7 5}$ 567-578. (doi:10.1016/0092-8674(93)90390-C)

Shaffer PL \& Gewirth DT 2002 Structural basis of VDR-DNA interactions on direct repeat response elements. EMBO Journal 21 2242-2252. (doi:10.1093/emboj/21.9.2242)

Shaffer PL, Jivan A, Dollins DE, Claessens F \& Gewirth DT 2004 Structural basis of androgen receptor binding to selective androgen response elements. PNAS 101 4758-4763. (doi:10.1073/pnas.0401123101)

Shiau AK, Barstad D, Loria PM, Cheng L, Kushner PJ, Agard DA \& Greene GL 1998 The structural basis of estrogen receptor/coactivator recognition and the antagonism of this interaction by tamoxifen. Cell 95 927-937. (doi:10.1016/S0092-8674(00)81717-1)

Sierk ML, Zhao Q \& Rastinejad F 2001 DNA deformability as a recognition feature in the reverb response element. Biochemistry 40 12833-12843. (doi:10.1021/bi011086r)

Sierra ML, Beneton V, Boullay AB, Boyer T, Brewster AG, Donche F, Forest MC, Fouchet MH, Gellibert FJ, Grillot DA et al. 2007 Substituted 2-[(4-aminomethyl)phenoxy]-2-methylpropionic acid PPAR $\alpha$ agonists. 1. Discovery of a novel series of potent HDLc raising agents. Journal of Medicinal Chemistry 50 685-695. (doi:10.1021/ jm058056x)

Sladek FM, Zhong WM, Lai E \& Darnell JE Jr 1990 Liver-enriched transcription factor HNF-4 is a novel member of the steroid hormone receptor superfamily. Genes and Development 4 2353-2365. (doi:10.1101/gad.4.12b.2353)

Solomon IH, Hager JM, Safi R, McDonnell DP, Redinbo MR \& Ortlund EA 2005 Crystal structure of the human LRH-1 DBD-DNA complex reveals Ftz-F1 domain positioning is required for receptor activity. Journal of Molecular Biology 354 1091-1102. (doi:10.1016/j.jmb.2005.10.009)

Stauffer SR, Coletta CJ, Tedesco R, Nishiguchi G, Carlson K, Sun J, Katzenellenbogen BS \& Katzenellenbogen JA 2000 Pyrazole ligands: structure-affinity/activity relationships and estrogen receptor$\alpha$-selective agonists. Journal of Medicinal Chemistry 43 4934-4947. (doi:10.1021/jm000170m)

Stehlin-Gaon C, Willmann D, Zeyer D, Sanglier S, Van Dorsselaer A, Renaud JP, Moras D \& Schule R 2003 All-trans retinoic acid is a ligand for the orphan nuclear receptor ROR $\beta$. Nature Structural Biology 10 820-825. (doi:10.1038/nsb979)

Sun J, Meyers MJ, Fink BE, Rajendran R, Katzenellenbogen JA \& Katzenellenbogen BS 1999 Novel ligands that function as selective estrogens or antiestrogens for estrogen receptor- $\alpha$ or estrogen receptor- $\beta$. Endocrinology 140 800-804. (doi:10.1210/en.140.2.800)

Sun J, Huang YR, Harrington WR, Sheng S, Katzenellenbogen JA \& Katzenellenbogen BS 2002 Antagonists selective for estrogen receptor $\alpha$. Endocrinology 143 941-947. (doi:10.1210/en.143.3.941)

Sun J, Baudry J, Katzenellenbogen JA \& Katzenellenbogen BS 2003 Molecular basis for the subtype discrimination of the estrogen receptor- $\beta$-selective ligand, diarylpropionitrile. Molecular Endocrinology 17 247-258. (doi:10.1210/me.2002-0341)

Takacs M, Petoukhov MV, Atkinson RA, Roblin P, Ogi FX, Demeler B, Potier N, Chebaro Y, Dejaegere A, Svergun DI et al. 2013 The asymmetric binding of PGC- $1 \alpha$ to the ERR $\alpha$ and $\mathrm{ERR} \gamma$ nuclear receptor homodimers involves a similar recognition mechanism. PLOS ONE 8 e67810. (doi:10.1371/journal.pone.0067810)

Tanenbaum DM, Wang Y, Williams SP \& Sigler PB 1998 Crystallographic comparison of the estrogen and progesterone receptor's ligand binding domains. PNAS 95 5998-6003. (doi:10.1073/pnas.95.11.5998) 
Umesono K \& Evans RM 1989 Determinants of target gene specificity for steroid/thyroid hormone receptors. Cell 57 1139-1146. (doi:10.1016/ 0092-8674(89)90051-2)

Umesono K, Murakami KK, Thompson CC \& Evans RM 1991 Direct repeats as selective response elements for the thyroid hormone, retinoic acid, and vitamin D3 receptors. Cell 65 1255-1266. (doi:10.1016/00928674(91)90020-Y)

Wagner RL, Huber BR, Shiau AK, Kelly A, Cunha Lima ST, Scanlan TS, Apriletti JW, Baxter JD, West BL \& Fletterick RJ 2001 Hormone selectivity in thyroid hormone receptors. Molecular Endocrinology 15 398-410. (doi:10.1210/me.15.3.398)

Wang Z, Benoit G, Liu J, Prasad S, Aarnisalo P, Liu X, Xu H, Walker NP \& Perlmann T 2003 Structure and function of Nurr1 identifies a class of ligand-independent nuclear receptors. Nature 423 555-560. (doi:10.1038/nature01645)

Watkins RE, Maglich JM, Moore LB, Wisely GB, Noble SM, Davis-Searles PR, Lambert MH, Kliewer SA \& Redinbo MR 20032.1 A crystal structure of human PXR in complex with the St. John's wort compound hyperforin. Biochemistry 42 1430-1438. (doi:10.1021/bi0268753)

Watson LC, Kuchenbecker KM, Schiller BJ, Gross JD, Pufall MA \& Yamamoto KR 2013 The glucocorticoid receptor dimer interface allosterically transmits sequence-specific DNA signals. Nature Structural \& Molecular Biology 20 876-883. (doi:10.1038/nsmb.2595)

Williams S, Bledsoe RK, Collins JL, Boggs S, Lambert MH, Miller AB, Moore J, McKee DD, Moore L, Nichols J et al. 2003 X-ray crystal structure of the liver $\mathrm{X}$ receptor $\beta$ ligand binding domain: regulation by a histidinetryptophan switch. Journal of Biological Chemistry 278 27138-27143. (doi:10.1074/jbc.M302260200)

Wilson TE, Fahrner TJ \& Milbrandt J 1993 The orphan receptors NGFI-B and steroidogenic factor 1 establish monomer binding as a third paradigm of nuclear receptor-DNA interaction. Molecular and Cellular Biology 13 5794-5804.

Wurtz JM, Bourguet W, Renaud JP, Vivat V, Chambon P, Moras D \& Gronemeyer H 1996 A canonical structure for the ligand-binding domain of nuclear receptors. Nature Structural Biology 3 87-94. (doi:10.1038/nsb0196-87)

Xu HE, Stanley TB, Montana VG, Lambert MH, Shearer BG, Cobb JE, McKee DD, Galardi CM, Plunket KD, Nolte RT et al. 2002 Structural basis for antagonist-mediated recruitment of nuclear co-repressors by PPAR $\alpha$. Nature 415 813-817. (doi:10.1038/415813a)

Yin L, Wu N, Curtin JC, Qatanani M, Szwergold NR, Reid RA, Waitt GM, Parks DJ, Pearce KH, Wisely GB et al. 2007 Rev-erb $\alpha$, a heme sensor that coordinates metabolic and circadian pathways. Science 318 1786-1789. (doi:10.1126/science.1150179)

Yin L, Ma H, Ge X, Edwards PA \& Zhang Y 2011 Hepatic hepatocyte nuclear factor $4 \alpha$ is essential for maintaining triglyceride and cholesterol homeostasis. Arteriosclerosis, Thrombosis, and Vascular Biology 31 328-336. (doi:10.1161/ATVBAHA.110.217828)

Yoon JC, Puigserver P, Chen G, Donovan J, Wu Z, Rhee J, Adelmant G, Stafford J, Kahn CR, Granner DK et al. 2001 Control of hepatic gluconeogenesis through the transcriptional coactivator PGC-1. Nature 413 131-138. (doi:10.1038/35093050)

Yu VC, Delsert C, Andersen B, Holloway JM, Devary OV, Naar AM, Kim SY, Boutin JM, Glass CK, Rosenfeld MG et al. 1991 RXR $\beta$ : a coregulator that enhances binding of retinoic acid, thyroid hormone, and vitamin D receptors to their cognate response elements. Cell 67 1251-1266. (doi:10.1016/0092-8674(91)90301-E)

Zechel C, Shen XQ, Chambon P \& Gronemeyer H 1994a Dimerization interfaces formed between the DNA binding domains determine the cooperative binding of RXR/RAR and RXR/TR heterodimers to DR5 and DR4 elements. EMBO Journal 13 1414-1424.

Zechel C, Shen XQ, Chen JY, Chen ZP, Chambon P \& Gronemeyer H $1994 b$ The dimerization interfaces formed between the DNA binding domains of RXR, RAR and TR determine the binding specificity and polarity of the full-length receptors to direct repeats. EMBO Journal 13 1425-1433.

Zhang J, Chalmers MJ, Stayrook KR, Burris LL, Garcia-Ordonez RD, Pascal BD, Burris TP, Dodge JA \& Griffin PR 2010 Hydrogen/deuterium exchange reveals distinct agonist/partial agonist receptor dynamics within vitamin D receptor/retinoid X receptor heterodimer. Structure 18 1332-1341. (doi:10.1016/j.str.2010.07.007)

Zhang J, Chalmers MJ, Stayrook KR, Burris LL, Wang Y, Busby SA, Pascal BD, Garcia-Ordonez RD, Bruning JB, Istrate MA et al. 2011 DNA binding alters coactivator interaction surfaces of the intact VDR-RXR complex. Nature Structural \& Molecular Biology 18 556-563. (doi:10.1038/ nsmb.2046)

Zhao Q, Khorasanizadeh S, Miyoshi Y, Lazar MA \& Rastinejad F 1998 Structural elements of an orphan nuclear receptor-DNA complex. Molecular Cell 1 849-861. (doi:10.1016/S1097-2765(00)80084-2)

Zhao Q, Chasse SA, Devarakonda S, Sierk ML, Ahvazi B \& Rastinejad F 2000 Structural basis of RXR-DNA interactions. Journal of Molecular Biology 296 509-520. (doi:10.1006/jmbi.1999.3457)

Zhou XE, Suino-Powell KM, Xu Y, Chan CW, Tanabe O, Kruse SW, Reynolds R, Engel JD \& Xu HE 2011 The orphan nuclear receptor TR4 is a vitamin A-activated nuclear receptor. Journal of Biological Chemistry 286 2877-2885. (doi:10.1074/jbc.M110.168740)

Received in final form 26 September 2013

Accepted 7 October 2013

Accepted Preprint published online 8 October 2013
() 2013 Society for Endocrinology Printed in Great Britain
Published by Bioscientifica Ltd 